Rhode Island College

Digital Commons @ RIC

Master's Theses, Dissertations, Graduate

Master's Theses, Dissertations, Graduate Research and Major Papers Overview

Research and Major Papers

$12-1-2019$

\title{
Methadone Use in Postoperative Pain Management: A Systematic Review
}

Olivia Mahoney

Follow this and additional works at: https://digitalcommons.ric.edu/etd

Part of the Nursing Commons

\section{Recommended Citation}

Mahoney, Olivia, "Methadone Use in Postoperative Pain Management: A Systematic Review" (2019).

Master's Theses, Dissertations, Graduate Research and Major Papers Overview. 316.

https://digitalcommons.ric.edu/etd/316

This Major Paper is brought to you for free and open access by the Master's Theses, Dissertations, Graduate Research and Major Papers at Digital Commons @ RIC. It has been accepted for inclusion in Master's Theses, Dissertations, Graduate Research and Major Papers Overview by an authorized administrator of Digital Commons @ RIC. For more information, please contact digitalcommons@ric.edu. 


\section{METHADONE USE IN POSTOPERATIVE \\ PAIN MANAGEMENT: A SYSTEMATIC REVIEW}

A Major Paper Presented

by

Olivia Mahoney

Approved:

Committee Chairperson

Committee Members

(Date)

Committee Menbers

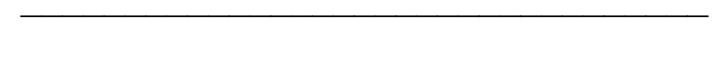

(D) (Date)

(Date)

Director of Master's Program

(Date)

Dean, School of Nursing 


\section{METHADONE USE IN POSTOPERATIVE \\ PAIN MANAGEMENT: A SYSTEMATIC REVIEW}

by

\section{Olivia Mahoney}
A Major Paper Submitted in Partial Fulfillment
of the Requirements for the Degree of
Master of Science in Nursing
in

The School of Nursing

Rhode Island College

2019 


\begin{abstract}
Postoperative pain is a commonly discussed topic in patients undergoing anesthesia for cardiac and thoracic surgery. Uncontrolled or poorly treated postoperative pain has been studied to cause poor outcomes in patients. Prolonged pain experienced by the patient can increase the risk of infection, respiratory compromise, development of chronic pain, and death. Current studies look at multiple modalities of treatment of postoperative pain, however, a long acting drug that is often under looked and underused is methadone. Methadone has a prolonged effect that can provide analgesia for an extended period of time. ). The purpose of this paper is to conduct a systematic review to determine if intraoperative methadone administration will affect postoperative pain after cardiothoracic and thoracic surgery as evidenced by pain score levels and documented postoperative opioid use. This systematic review was created using guidelines put forth by both PRISMA and CONSORT. A literature review was performed, and data was gathered from each study. A cross study analysis was performed using data collection tables designed by the author of this systematic review. Methadone was found to have a prolonged effect, but evidence was inconclusive due to many limitations by each of the studies. It is suggested that methadone should be further evaluated in additional systematic reviews.
\end{abstract}




\section{Acknowledgements}

The greatest part of this accomplishment is who I am able to share it with. I would like to thank my friends and family for their unwavering support through this arduous journey. Keith, I feel truly lucky to be yours, thank you for never doubting me. I deeply appreciate your ability to always make me laugh and all of the sacrifices you've made to make this possible. Mom and Dad, thank you for always knowing my path, but always letting me find the way on my own. This accomplishment is a product of your love and support, I could not have asked for better role models. 
Table of Contents

Background/Statement of Problem..............................................

Literature Review....................................................4

Theoretical Framework...................................................27

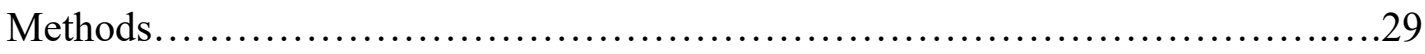

Results................................................................ 36

Summary and Conclusions............................................. 52

Recommendations and Implications for Advanced Nursing Practice..............57

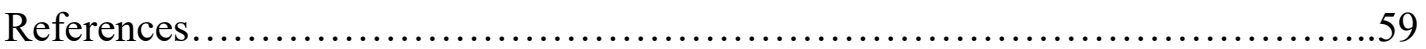

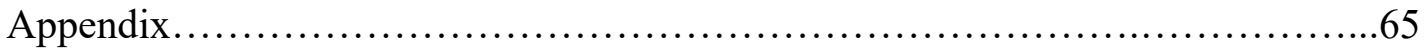




\section{Background/Statement of the Problem}

Surgery is one of the most predictable and common sources of pain in hospitalized patients and is an expected outcome for patients undergoing some type of surgical intervention or procedure. Incisions through layers of tissue and muscle, along with the trauma of the surgical procedure itself can cause a variety in intensity of pain in the surgical setting. In 2010, the performance of 48.3 million surgical and nonsurgical procedures were recorded as visits to both ambulatory surgical centers and hospitals (Hall, Schwartzman, Zhang \& Liu, 2017). It is estimated that in over $80 \%$ of surgical patients within the United States, postoperative pain is not sufficiently managed (Gan, 2017). While this statistic widely varies with type of surgical procedure, the medications and anesthetics used intra-operatively and postoperatively, complications, and time elapsed after surgery, the results remain significant (Gan, 2017). Poorly controlled postoperative pain in the acute stages increase morbidity risk, impair functional and quality of life, delay recovery time, increase health care cost, and increase the duration of opioid usage (Gan, 2017). The presence and high intensity of acute pain in the postsurgical setting highly correlates with the development of chronic pain (Gan, 2017). Furthermore, the development of chronic pain contributes to disability, interferes with routine activities and employment, further increases healthcare spending, reduces quality of life and can contribute to mortality.

Multiple modalities of pain management can be offered by providers, but preference to certain drugs can impact the provider's choice of management, rather than patient specific considerations. A provider's lack of understanding regarding 
pathophysiology of pain, or the pharmacodynamics of the large variety of drugs can limit options considered for pain management. This practice potentially excludes the use of medications that have properties that would allow for the most optimal patient outcomes. The standard of care for pain management in the acute postoperative phase is still opioid prescriptions (Gan, 2017).

The Joint Commission is an organization involved in accreditation of healthcare organizations with the aim to continuously improve the quality and safety of care that is provided to the public (The Joint Commission, 2018). The commission evaluates aspects of healthcare and creates standards and goals in which healthcare providers are urged to follow to support performance improvements in health care organizations throughout The United States. In 2001, The Joint Commission noted the underassessment and undertreatment of pain and introduced standards for providers to appropriately monitor, document and treat pain (The Joint Commission, 2017). In addition to these standards, The American Society of Anesthesiologists (ASA) developed guidelines to assist providers in selecting pain management options in the perioperative phase, however, nationwide protocols are not in place for types of procedures, with regard to specific type of pain management techniques (The American Society of Anesthesiologists, 2012). Since surgical patients may range in age, comorbidities, pain tolerance, allergies, and medication side effects, and more, standards are difficult to develop in offering providers a protocol to follow while managing pain, especially in the postoperative period. Additionally, anesthetic management throughout the perioperative period is typically patient specific and individualized to patient needs. Furthermore, with recent issues 
surrounding the opioid epidemic and abuse of prescription drugs in the United States, providers are left confused and less willing to write prescriptions that would offer adequate pain management, fearing abuse and addiction (The Joint Commission, 2017). One drug in the method of pain management that is typically overlooked is the use of methadone. Methadone is a synthetic opioid with similar properties to morphine. It has a much longer duration of action, which ranges widely among individuals, which could allow for improvement of pain management in the postoperative phase. It is commonly noted as one of the main drugs of choice for treatment of drug dependence and is often overlooked in pain management in the perioperative setting (Kharasch, 2011). The purpose of this paper is to conduct a systematic review to determine if intraoperative methadone administration will affect postoperative pain after cardiothoracic and thoracic surgery as evidenced by pain score levels and documented postoperative opioid use.

Next, a review of the literature will be presented. 


\section{Literature Review}

An extensive search of literature was performed using the following databases: CINAHL, PubMed, Ovid, Medline Plus and Cochrane Library. The search was limited to articles by the following factors: published in the English language from 1990 throughout the current year and those applicable to subject topic. Search terms included: "pain," "pain management," "cardiothoracic surgery," "cardiac surgery," “thoracic surgery," "methadone," "postoperative pain," "acute pain,” and "chronic pain.”

\section{Pain Definition and Etiology}

Defined by The International Association for the Study of Pain (IASP), pain is defined as "an unpleasant sensory and emotional experience associated with actual or potential tissue damage or described in terms of such damage" (IASP, 2017). While pain is typically evaluated as a negative experience, it has had a positive impact on the human species. Often, pain can indicate certain health issues, such as disruption in normal organ function, injury, infection or cancerous lesion.

One of the most commonly known causes of pain is related to surgical procedures or medical interventions. The perioperative phase involves all phases of surgery, including preoperative and postoperative. Pain can occur in all of these phases. Patients may experience pain in the preoperative period, otherwise known as the period prior to surgery, which can be related or unrelated to their planned procedure. During the intraoperative phase, or the time the patient is being treated within the operating room, patients are exposed to many types of painful stimuli, such as initial incision or uncomfortable positioning required to complete the planned procedure. Lastly, the most 
common occurrence of pain in the perioperative setting is postoperatively, or the period of time after the surgery and during the patient's period of recovery. In addition to an unpleasant sensation, pain throughout the entire perioperative phase can contribute to negative effects on patient's health and recovery, including prolonged hospital stays, which can further lead to increased co-morbidities and complications (Hutchinson, 2007).

The etiology of pain is rather complex but can be simplified into an overall neurological-sensing pathway. Disruptions in normal tissue integrity caused by mechanical, thermal or chemical means cause nociceptive neurons to increase the rate of discharge and send signals to the brain for the body to recognize the sensation of pain (Carr \& Goudas, 1999). Depending on the type and degree of pain, nociceptors can have different responses and the rate of discharge based on the stimulus intensity (Carr \& Goudas, 1999). In a state of tissue destruction and the activation of nociceptors, the body emits a local inflammatory, immune and mediated cell responses (Car \& Goudas, 1999). Nociceptive information is then conveyed from the site of pain to the dorsal horn of the spinal cord and through the thalamic, limbic, and cortical structures that are accountable for the perception of the affective and discriminative responses to the body (Carr \& Goudas, 1999).

Acute pain is a type of pain that is often experienced in the perioperative phases. It is defined as pain that is short in duration and serves the purpose of warning of illness or injury, hence stimulating the sympathetic nervous system to elicit the "fight or flight" response (Helms \& Barone, 2008). This response includes increased heart rate and respiratory rate, apprehension, restlessness, sweating and dilated pupils; symptoms that 
can be recognized and objectively measured by providers in operative patients (Helms \& Barone, 2008). Different subsets of acute pain include somatic, visceral and referred. Somatic pain is related to pain elicited at, or near skin or subcutaneous tissues, visceral pertains to the internal organs, and referred pain is pain that is felt in an area distant from the stimulus site (Helms \& Barone, 2008). Diseases, injury, trauma and surgical incisions can elicit all three of these types of acute pain.

\section{Postoperative Pain}

Postoperative pain is pain that is felt after a surgical procedure or intervention and varies greatly among patients. Acute pain in the immediate post-surgical setting is typically due to the activation of nociceptors, inflammatory mechanisms, and possible nerve injury (Kehlet, Jensen \& Woolf, 2006). For this reason, in the initial phases, pain is often described by patients as a spontaneous throbbing or discomfort while resting, in addition to breakthrough pain at the surgical site and surrounding tissues after pain medication has been administered (Kehlet et al., 2006). Movement to the affected surgical location, touching, breathing, coughing, and poor gastrointestinal mobility after surgery, are further factors that can evoke or increase the pain experience (Kehlet, et al., 2006).

Despite the increasing awareness of pain and the many guidelines set forth to manage postoperative pain, it still remains a major challenge in patients who undergo surgical procedures. According to The Institute of Medicine (2011), approximately 60\% of surgical procedures within the United States are performed within outpatient settings and patients are discharged to home the same day. In this population, adequate pain 
assessments may not be accurately assessed. Patients are likely to be discharged to home with lingering anesthetics, opioids or regional nerve blocks, and may not experience a high level of postoperative pain upon discharge, in comparison to the amount of pain they may feel once they are at home, hours later. Inadequate pain management, or poor choice in pain management strategy, can have a large impact on reported pain after surgery. In addition, patients may not comply with pain regimen, may not understand the education they received regarding treatment of pain, or be fearful to take opioids causing inadequate pain relief, or on the contrary, inappropriately self-manage prescription drug dosages or scheduling (Jafra \& Mitra, 2018).

Postoperative Pain Evaluation. Apfelbaum, Chen, Mehta and Gan (2003) hypothesized that although pain is a common experience following surgery, it is inadequately managed in most surgical populations. They further emphasized that postoperative pain has profound consequences on patient's health and recovery. In a survey of 250 post-surgical patients, Apfelbaum, et al., (2003) found that $80 \%$ of respondents that had any type of surgery in the past five years reported acute pain after a variety of surgical procedures, ranging from those performed within hospital inpatient, outpatient, physician office or outpatient surgical centers. Of this $80 \%$ reporting acute pain, $75 \%$ further reported pain after they had been discharged, in comparison to $58 \%$ of patients who reported pain prior to discharge (Apfelbaum et al., 2003). The study also reported that $59 \%$ of patients expressed their primary concern for surgery was the experience of postoperative pain, and $8 \%$ postponed their procedures due to fear of postoperative pain (Apfelbaum et al., 2003). 
In a study conducted by Zheng et al. (2017), 890 patients were evaluated after orthopedic surgery with regard to the impact on postoperative pain and compared variables such as age, sex, preoperative chronic pain and anesthetic technique. The authors found the most significant differences in postoperative pain reporting were in patients who were older than 50 years, female, or those with preoperative chronic pain. The researchers used questionnaires to inquire about postoperative pain intensity, interference of pain with activities and feelings, side effects of medications administered, and the satisfaction of the care received (Zheng et al., 2017). Zheng at al. (2017) found that the mean amount of time spent in severe pain was $30 \%$, and women reported a longer period of time in severe pain than men $(p<0.001)$. All patients reported that their postoperative pain interfered with physical activities, and on the numerical rating scale (NRS) evaluating anxiety and helplessness, all patients reported an increased anxiety level of $2.40 \pm 2.46$, related to their pain (Zheng et al., 2017). In addition, all patients reported the feeling of helplessness due to pain at $2.68 \pm 2.87$ on the NRS (Zheng et al., 2017).

Zheng et al. (2017), found that the mean postoperative opioid consumption in all patients was $0.346 \mathrm{mg} / \mathrm{kg}( \pm 0.456)$ morphine equivalents $(\mathrm{ME})$, with women using more opioids than men. Female consumption was measured at $0.39 \mathrm{mg} / \mathrm{kg} \pm 0.50(\mathrm{ME})$ and male was $0.31 \mathrm{mg} / \mathrm{kg} \pm 0.41(\mathrm{ME})$ (Zheng et al., 2017). Despite the increased consumption of opioids in women, both gender groups reported the mean amount of pain relief was $62 \%( \pm 27 \%)$, and Zheng et al. (2017) inferred that sex differences did not show significance in pain intensity ratings. Age was also evaluated in two groups and 
compared by participants under the age of 50 to those over the age of 50 . Analysis of these groups showed that the older age group of women received a significantly reduced amount of pain relief compared to men $(p=0.040)$. In contrast, the younger age group of women experienced a higher amount of pain relief than compared to the men $(p=0.025)$. Zheng et al. (2017) reported $17.7 \%$ of all patients included in the study stated they would have preferred to receive better pain management. The mean satisfaction among all the patients in the study was $7.57( \pm 2.77)$ on a numerical rating scale $0-10$ (Zheng et al., 2017).

Although pain is an anticipated experience after surgery, it is also a highly feared sensation and can impede patients from seeking surgical treatments. In the two studies by Zheng et al., (2017) and Apfelbaum et al. (2003), pain is highlighted as a serious condition that can greatly interfere with patient's well-being, satisfaction and even contribute to chronic pain syndromes. It is important to trend factors, such as age, gender, preoperative pain, amount of opioid administered, and postoperative pain scores, in order to understand and formulate effective treatment strategies.

Measurement of Postoperative Pain. Pain is considered a subjective sensation and patients self-reporting of pain is one of the primary considerations in the plan of care. Pain intensity measurements are a prerequisite in the decision of treatment modalities for proper pain management (Nagelhout \& Plaus, 2014). Reporting scales, such as the visual analog scale (VAS) and the numerical rating scale (NRS) assess level of pain and are clinically relevant in measuring pain intensity (Nagelhout \& Plaus, 2014). Each scale uses the goal to allow the patient to assign a value to level of pain they are experiencing. 
This information can be used to direct the provider in formulating the most effective type of treatment and dose.

Visual Analog Scale. The VAS is a continuous scale consisting of $100 \mathrm{~mm}$ vertical or horizontal lines with extremes labeled as worst imaginable pain and zero pain (Kliger et al., 2014). Patients are instructed to mark the intensity of the pain being felt on a line between the two extremes. This option allows providers to monitor the amount of pain the patient is experiencing, and plan strategies based on that exam. The VAS does not require the patient to have verbal or reading skills and is versatile and can be used in a wide variety of settings (Kliger et al., 2014). Disadvantages of this scale include the requirement of visual acuity and the patient's ability to convert pain experience to an abstract scale (Kliger et al., 2014). For these reasons, it has been reported the VAS has a failure rate of $7-16 \%$, especially in elderly, young children, handicapped and mentally challenged populations of patients (Kliger et al., 2014).

Numeric Rating Scale. Similar to the VAS, the NRS is an 11-point scale that patients use to provide a value from 0-10 regarding the intensity of their pain. A score of 0 indicates no pain and a score of 10 indicated the worst imaginable pain (van Dijk, Kappen, Schuurmans, \& van Wijck, 2014). The VAS and NRS are very similar in approach to acquiring pain score from an individual, although the VAS has a visual key that can be utilized by the patient to point to, rather than the NRS in which patients typically assign a number to their pain without the use of visual aids. Therefore, these two scales have similar advantages and disadvantages. The ease of the NRS, and lack of visual requirements make this assessment technique more popular in the clinical setting. 
In addition, pain management strategies are often prescribed based on the NRS value the patient reports. Providers may write prescriptions for certain medications or opioids for pain management if the NRS level is above 3 or 4 , with incremental dosage increase, depending on patient NRS score (van Dijk et al., 2014).

Disadvantages. Both pain scales typically lack consideration of patient age or cognitive level, in which developmental function may influence pain scores (Nagelhout \& Plaus, 2014). Additionally, they lack depth of determining the quality of the pain and other possible exacerbating or associated factors that could affect pain (Nagelhout \& Plaus, 2014). Patient understanding of rating pain on the scale is crucial, and may be influenced by patient culture, pain history, or tolerance to pain.

Postoperative Pain after Thoracic Surgery. Thoracic surgery is inclusive of surgical procedures involving the thoracic cage, and can include: airway, esophagus, lungs, diaphragm, chest wall, and heart. A wide variety of factors cause pain after thoracic surgery, including: tissue retraction, vein harvesting, artery dissection, along with prolonged surgery and sustained uncomfortable position throughout the procedure (Bignami et al., 2018). In addition, inflammation of tissue triggered by the trauma induced by intended surgical bone fractures and dislocations can create a significant amount of pain (Bignami et al., 2018). Along with the multiple painful factors of surgery itself, patients typically leave the operating room with drainage catheters, sternotomy and/or thoracotomy incisions, central venous access devices and more, which can have a large impact on pain scores (Bignami et al., 2018). 
Reported postoperative pain following thoracic surgery is often higher in the first two days after surgery and typically reported as more intense in young, female populations (Bignami et al., 2018). Multiple guidelines support positive patient outcomes when patients participate in early ambulation and advance diets within hours to a day after the surgical procedure (Sarin et al., 2016). Coughing, deep breathing, eating and increasing activity level can contribute to pain and result in patient apprehension to continue activity, but can speed overall recovery rates, lessen duration of pain and minimize its consequences (Sarin et al., 2016).

Studies of postoperative pain after thoracic surgery. Guastella et al. (2011) conducted a prospective study of 54 patients to evaluate pain following thoracic surgery. The study evaluated patients that underwent a thoracotomy with a single surgical team using standardized approaches for the surgery and analgesic management. The population reported NRS scores $<3$ in the first 72 hours after surgery when using a pain regimen protocol. Two months after surgery, 49 patients $(91 \%)$ reported continued thoracic pain and of those, 12 patients were still using analgesics. At 6 months, 7 patients were excluded from the study due to lack of follow up, and 38 of 42 , or $90.4 \%$, of patients reported persistent postoperative pain. $30.9 \%$ of those patients reported still using analgesics, and 2 patients transitioned to antidepressants for pain management (Guastella et al., 2011). At the six-month evaluation, three patients were additionally lost in follow up due to difficulties in correctly evaluating pain, leaving a total of 35 patients remaining for further evaluation for chronic postoperative pain. Of this group of patients, the mean NRS score was $3.93 \pm 2.3$, and of the 13 patients still utilizing pain treatment, NRS was 
$6.16 \pm 2.1$. Spontaneous pain at incision or surgical area was reported by $86 \%$ of patients, most commonly referred to as throbbing, shock-like and wrenching pain (Guastella et al., 2011).

In a prospective observational study by Wang et al., (2017), 300 patients were evaluated for pain intensity following thoracic surgery in the immediate first seven days of surgery and then in intervals, up to 6 months after surgery. The study reported that in the first 2 days after surgery, using the NRS, approximately $65 \%$ of patients reported moderate to severe pain with movement, which decreased to $30 \%$ of patients by postoperative days (PTD) 4-7 (Wang et al., 2017). Pain intensity with coughing was also reported as moderate to severe in $85 \%$ of patients PTD $1-2$, with a decrease in $65 \%$ of moderate to severe by PTD 4-7 (Wang et al., 2017). In patients reevaluated at six months after their surgery, 48.9\% reported continued, chronic pain (Wang et al., 2017). The authors also concluded that patients were more reluctant to request pain management when desired, especially if not properly educated regarding the importance of pain management or were not aggressive in treating pain before severe levels occurred (Wang et al., 2017).

\section{Pharmacological Options}

Current clinical guidelines for the management of postoperative pain have evolved over recent years in response to the reported high levels of pain after surgical procedures. In the past few decades, providers have relied heavily on the use of medications that hold a shorter half-life, thus providing a shorter duration of action (Kharasch, 2011). This can 
lead to uncontrolled pain after surgery, which may become difficult to manage once it escalates to a higher level.

With input from the American Society of Anesthesiologists (ASA), The American Pain Society created an interdisciplinary panel of experts in pain management to decipher and promote evidenced based, safe, postoperative pain management in adults and children (Chou et al., 2016). As part of the guideline process, the expert panel review conducted a systematic review, including a review of the literature to evaluate different aspects of pain management in relation to various interventions and management strategies of postoperative pain. Chou et al., (2016) formulated recommendations based on their findings that addressed different aspects of postoperative pain. The recommendations include: preoperative patient education, perioperative pain management techniques and planning, multimodal approach of pharmacological and nonpharmacological treatment modalities, organizational policies and the transition of patient care to an outpatient setting (Chou et al., 2016). The foundation of optimal postoperative pain management includes the premise that treatment of postoperative pain is initiated in the preoperative phase with patient centered assessments, and plan that focuses on the individual and proposed surgical procedure (Chou et al., 2016).

Patient Controlled Analgesia. Patient controlled analgesia (PCA) is widely used in postoperative management of pain. The use of this method allows for patients to press a button, programmed by a pump, and the patient is able to deliver a dose of pain medication when they feel pain and wish to seek relief. PCA pumps are programmed by the provider and control parameters are set, including bolus dose, lockout interval, dose 
limits and loading dose of the medication upon establishment of the pump (Kuo, Chang, Juan, Hsu, Chan \& Tsou, 2018). If deemed necessary, the provider can also program the PCA to deliver a continuous infusion of the opioid in addition to the controlled doses the patient can receive. The PCA maintains a log of records of all events pertaining to the therapy, including amount of patient demand and amount of opioid delivered over a period of time. Patients utilize the PCA in the first few hours or days after surgery and are commonly switched to oral pain medication. Although a highly effective method of providing pain relief after surgery, it also carries risks, including: respiratory depression, respiratory arrest or even death, if not properly and closely monitored (Kharasch, 2011).

Neuraxial Analgesia. Central neuraxial anesthesia is the placement of anesthetic solution onto, or adjacent to, the spinal cord, and includes spinal and epidural anesthesia (Nagelhout \& Plaus, 2014). Due to the location of the desired sensory blockade in thoracic surgery, spinal injections are contraindicated, but epidurals can be utilized (Nagelhout \& Plaus, 2014). An epidural injection can be performed with an attached catheter that can be used for multiple doses of anesthetics or pain medication, throughout a procedure, and later in the postoperative phase (Nagelhout \& Plaus, 2014). Multiple advantages of epidural catheters exist, such as allowing the patient to use a patient controlled epidural analgesia (PCEA) to deliver medications by the epidural catheter and decreased risk of: venous thrombosis, myocardial infarction, respiratory depression and pneumonia (Chou et al., 2016).

Chou et al. (2016) further found that in the treatment of thoracic perioperative pain, current guidelines recommend neuraxial analgesia, such as epidural anesthesia, 
especially for patients at risk for pulmonary or cardiac complications. Chou et al. (2016) suggested that neuraxial analgesia with local anesthetics, is associated with decreased requirements for acute pain management, also referred by rescue analgesia.

Comparison. In a meta-analysis of randomized control trials conducted by Wu et al., (2005) PCEA provided significantly superior postoperative pain control compared to PCA, for up to three days after surgery. The meta-analysis included 50 articles that compared the use of PCA versus PCEA for pain control in postoperative pain management (Wu et al., 2005). The study then compared the type of surgery and pain scores. According to $\mathrm{Wu}$ et al. (2005), average pain scores for patients with a PCEA were $1.6 \pm 1.5$ of 1,157 patients, compared to PCA scores $2.7 \pm 1.8$ in 1,139 patients. The authors concluded that due to the ability of PCEA management to block nociceptive input to the central nervous system with the addition of opioids, compared to intravenous administration allowed for greater pain control (Wu et al., 2005). Unfortunately, neuraxial anesthesia is not always an option due to patient refusal, inadequate provider skill, unsuccessful insertion attempts, or other technical or medical reasons. A few of the main contraindications of neuraxial anesthesia include mitral or aortic stenosis and preoperative anticoagulation regimens, which are both highly typical of a patient planning to undergo cardiothoracic surgery (Nagelhout \& Plaus, 2014).

Oral and Intravenous Opioids. Systemic analgesics and adjunctive medications are the main alternative to invasive techniques and continue as the main approach for pain management following intraoperative procedures (Gottschalk, Cohen, Yang \& Ochroch, 2006). Opioids are still currently the main option for treatment of pain in all 
phases of surgery, especially in the postoperative phase. Intravenous administration is typically utilized intraoperatively and then converted to oral administration once the patient is able to eat and drink fluids. Unfortunately, opioids carry a significant risk of causing dependence, addiction and respiratory depression, especially in higher doses. To prevent these side effects, adjuvant medications, such as Nonsteroidal Anti-inflammatory Drugs (NSAIDs), acetaminophen, gabapentin and tramadol are often considered (Gottschalk et al., 2006).

\section{Consequences of Postoperative Pain}

Extended periods of postoperative pain can have significant consequences to patient's health and recovery physiologically and psychologically. In the initial postoperative phase, pain is considered acute, but if prolonged, it can become chronic pain.

Acute Postoperative Pain. Extended periods of unrelieved pain can cause a negative effect on every major organ within the human body. With regard to the endocrine system, pituitary-adrenal activation can occur and lead to impaired immunological function and increase the risk of postoperative wound infection (Hutchinson, 2007). This infection risk is noted as even higher than original surgical risk of infection (Hutchinson, 2007). Pain can increase sympathetic response that can cause negative effects to the cardiovascular, renal and gastrointestinal systems, which lead to vasoconstriction and reduced blood flow to vital organs. In addition, pain can cause patient apprehension related to ambulation, deep breathing exercises, nutrition, which are often important elements in recovery of the surgical patient (Hutchinson, 2007). 
Patients that receive adequate pain management enhance their ability to participate in early mobility, and thus lessen the risks of urinary retention, ileus, and myocardial infarction (Glowacki, 2015). In addition, with proper pain management, sleep deprivation which can later lead to postoperative fatigue and delirium, can be avoided. Prevention of postoperative fatigue can also enhance mobility after surgery, and reduce the amount of pulmonary complications (Glowacki, 2015).

Adverse Complications. As a result of the multiple complications listed, a wide range of potential adverse events can occur, such as deep vein thrombosis, pneumonia, wound infection, pulmonary embolism, myocardial infarction, and chronic pain syndrome (Hutchinson, 2007). Prolonged illnesses or complications can lead to mental health issues such as stress, depression, and anxiety (Hutchinson, 2007). Furthermore, beyond the medical issues, poor pain management can contribute to increased healthcare costs for the patient and provider. Prolonged hospital courses, readmissions and patient dissatisfaction are also factors that add to poor outcomes after surgery (Hutchinson, 2007).

According to Glowacki (2015), five dimensions contribute to pain management: physiological, sensory, affective, cognitive, and sociocultural components. Each dimension is crucial for patient evaluation with regard to management of acute pain. Aggressive pain control in the acute phases is still an underutilized technique, and despite guidelines and studies published to evaluate pain management, patients are still left somewhat unsatisfied. Glowacki (2015) infers that if all five dimensions of pain management are addressed, adverse complications of acute pain can be avoided. 
Chronic Postoperative Pain. According to the International Association for the Study of Pain (2002), chronic pain is defined as pain that recurs or persists within range beyond the healed incision site, at least two months after the surgical procedure. This pain can lead to immobility of surgical site and surrounding areas due to exacerbation of pain. Patients with suboptimal pain management in the acute phase after surgery are at risk of developing persistent pain which can then progress to chronic pain. This can lead to further and increased opioid requirements, tolerance and possible opioid addiction.

Chronic Pain Following Cardiac Surgery. In a prospective cohort study by van Gulik et al. (2011), 146 patients were evaluated following cardiac surgery via sternotomy. In all patients, anesthesia was standardized during induction and maintenance phases of the anesthetic approach. Pain was managed in the postoperative phase of surgery with a continuous infusion of morphine, in combination with acetaminophen (Gulik et al., 2011). Pain scores were evaluated during the initial seven days following the surgery and 10-12 months after the surgery by telephone interview by questionnaire and evaluation of NRS score. At 10-12 months following the surgery, 35\% reported the sensation of chronic thoracic pain and 29.2\% reported severe pain (Gulik et al., 2011). Additionally, regardless of type of thoracic procedure, such as Coronary Artery Bypass Graft (CABG), valve surgery, aortic and CABG combined with valve surgery, the incidence of chronic pain was the same among each surgery (van Gulik et al., 2011). Of the chronic pain sufferers, $14.3 \%$ reported minor or major pain that had influence on their daily life and had to stop working or reduce their work hours due to the pain (van Gulik et al., 2011). Van Gulik et al. (2011) did not find a difference in chronic 
pain scores of those patients that had previously undergone a sternotomy prior to the surgery being evaluated. Van Gulik et al. (2011) determined that several characteristics correlated with the development of chronic pain one year after cardiac surgery. These characteristics included: non-elective surgery, resternotomy shortly after the original surgery, female gender and severe pain on the third postoperative day (Gulik et al., 2011).

A prospective study conducted by Bayman, Parekh, Keech, Selte, and Brennan (2017) evaluated 99 patients at 3 and 6 months after thoracic surgery to evaluate for chronic pain. Two surgical methods were compared: thoracotomy and video assisted thorascopic surgery (VATS). Researchers found that chronic pain values measured at 3 and 6 months postoperatively by use of the NRS were similar among the two. The goal of the study was to detect predictors of chronic pain and to determine if acute pain played a significant role in the development of postoperative chronic pain. In the immediate postoperative phase, pain was managed with patient-controlled analgesia and measured in morphine equivalents. Researchers evaluated NRS scores in the first three days after surgery, in addition to the presence and amount of chest tubes each patient had. There were no differences in the average NRS in the preoperative or 3-day postoperative phase in either surgical groups. Bayman et al. (2017), found that the incidence of chronic pain in their study at 3 months after either surgery was prevalent in $34 \%$ of patients, and at 6 months, was $27 \%$. At 3 months, $16 \%$ of patients reported pain that limited daily activities, and at 6 months, $8.2 \%$ reported continued limitations (Bayman et al., 2017). The study linked the incidence of a higher severity of pain during the first three days 
postoperatively to a higher incidence of chronic pain lasting 6 months after the initial surgery.

\section{Methadone}

Methadone was introduced in 1940 as a synthetic opioid and contains the same potency and similar side effects as morphine when given intravenously (Barbosa Neto, et al., 2014). A close relationship between stereochemical structure and potency of opioids exists between naturally occurring morphine and synthetic methadone (Nagelhout \& Plaus, 2014). Methadone is considered a diphenylheptane derivative and holds a slightly similar molecular structure to morphine, comprised of two of the five natural ring structures seen in morphine (Nagelhout \& Plaus, 2014). Methadone and morphine both affect the same pain receptors, mu, kappa and delta (Nagelhout \& Plaus, 2014).

Structurally, methadone is a racemic mixture of d-isomer (S-methadone) and l-isomer (Rmethadone), which each component allowing for a different mechanism of pain control (Nagelhout \& Plaus, 2014). The d-isomer allows antagonization of the NMDA receptor, inhibiting uptake of norepinephrine and serotonin, which contributes to treatment of neuropathic pain and prevention of opioid tolerance (Nagelhout \& Plaus, 2014). The 1isomer binds to opioid receptors, therefore treating pain (Nagelhout \& Plaus, 2014). Methadone can be administered via oral, intravenous, subcutaneous, and rectal route (Nagelhout \& Plaus, 2014). When administered orally, methadone's peak effect is 30-60 minutes, and intravenously, effects are seen within 15-20 minutes (Nagelhout \& Plaus, 2014). 
In current practice, methadone is primarily used for treatment of chronic pain, opioid abstinence syndrome, and treatment of heroin addiction (Nagelhout \& Plaus, 2014). As compared to other opioids, it produces less euphoria and has a longer half-life, which allows for less frequent dosing requirements (Nagelhout \& Plaus, 2014). The elimination half-life, referred by the amount of time for half of the drug to be eliminated from the body, can range greatly among individuals, from 8-90 hours (Barbosa Neto, et al., 2014). This allows an extended period of duration of action from 4-8 hours (Barbosa Neto, et al., 2014). The prolongation of the drug and drug effect is partly due to the extensive protein binding it has within the body, which allows for a slow release and delayed metabolization of the drug (Nagelhout \& Plaus, 2014). In addition, methadone has a high bioavailability and is not associated with active metabolites (Nagelhout \& Plaus, 2014).

\section{Methadone: Role in Postoperative Pain Management}

Multilevel Thoracolumbar Spine Surgery. The use of methadone in the surgical population has been widely studied in various types of surgeries, such as spinal surgery and total hip arthroplasty. In recent studies, methadone has been compared to other, shorter acting drugs and evaluated for efficacy and pain control in the postoperative phase. In a randomized control trial conducted by Gottschalk, Durieux, and Nemergut (2011), a single dose of intraoperative methadone was compared to a continuous infusion of sufentanil, a short acting opioid, in patients undergoing lumbar spinal surgery. The population included 29 patients that underwent multilevel thoracolumbar spine surgery. Pain was reassessed at 24, 48, and 72 hours after surgery (Gottschalk et al., 2011). 
Patient demographics in each of the groups were similar with respect to age, sex, body weight and height, body mass index and American Society of Anesthesiologists (ASA) status.

Gottschalk et al., (2011), found that the preoperative opioid use, preoperative pain scores, length of surgery, time to extubation, estimated blood loss, and intraoperative crystalloid or colloid requirements were comparable between both groups. Pain after surgery was reported to be significantly less and more statistically significant 48 hours after extubation in the methadone group. To effectively compare the two medications, dosages were converted to morphine equivalents. In the sufentanil versus methadone group, at 48 hours postoperative, morphine equivalents were measured at $63 \mathrm{mg}$ versus 25 $\mathrm{mg}$, and at 72 hours after surgery $34 \mathrm{mg}$ versus $15 \mathrm{mg}$ (Gottschalk et al., 2011). In addition to these findings, the study proved that pain scores were approximately $50 \%$ lower in the methadone group versus the sufentanil group at 48 hours after surgery (Gottschalk et al., 2011). Gottschalk et al., (2011), inferred that perioperative use of one single bolus of methadone improves postoperative pain control and allows a reduction of additional opioid requirements in patients undergoing complex spine surgery.

Pacreau, Candil, Carazo and Galinski (2012) evaluated the intraoperative use of methadone versus methadone mixed with ketamine on postoperative opioid consumption in 22 patients undergoing multilevel lumbar arthrodesis. The MK group, methadone mixed with ketamine, received a pre-incisional bolus of intravenous racemic ketamine $0.5 \mathrm{mg} / \mathrm{kg}$, followed by an infusion of $2.5 \mathrm{mg} / \mathrm{kg} / \mathrm{min}$ of methadone. The patients in the control group, ME group, received a bolus of saline and an infusion of $2.5 \mathrm{mg} / \mathrm{kg} / \mathrm{min}$ of 
methadone. Postoperatively at 24-48 hours, each patient group was given a PCA administering $1 \mathrm{ml}$ bolus, with a lockout of 10 minutes and maximum of 3 boluses per hour. In the MK group, the PCA contained $0.25 \mathrm{mg}$ of methadone plus $0.5 \mathrm{mg}$ of ketamine and the ME group contained $0.5 \mathrm{mg}$ of methadone.

Strict methods and protocols were held for induction of anesthesia and held throughout the patients' operative time. Postoperatively, the NRS value was evaluated and recorded, and $2 \mathrm{mg}$ of methadone boluses were administered every 15 minutes until the NRS scale was equal or less than 3, and then the PCA was started. A blinded team member recorded the NRS value at rest and at movement, at 24 and 48 hours. Also recorded was the amount of consumption of opioid delivered, the demanded doses and the delivery to demand ratio.

Pacreau et al. (2012) found that the difference between the consumption of methadone at 24 hours by PCA was an average of $15 \mathrm{mg}$ for the ME group versus $3.4 \mathrm{mg}$ for the MK group. At mobilization, pain average for MK group was 4.5 and for ME group 6 on the NRS scale (Pacreau et al., 2012). Pacreau et al. (2012) found that while methadone is an effective drug for postoperative pain, the use of methadone with an adjunctive treatment for pain provided a significant level of pain control, as evidenced by lower pain scores and decreased opioid intake.

Total Hip Arthroplasty. Barbosa Neto et al., (2014) conducted a randomized, double blind, controlled, parallel group study comparing the pain management of 34 patients that underwent a Total Hip Arthroplasty (THA) and received postoperative morphine PCA versus methadone PCA. Surgery was performed under spinal anesthesia 
by the same surgical team using similar surgical approaches in each of the groups. Drug potency ratio was 1:1 to compare and convert total morphine to methadone consumption. During the postoperative phase, patients were assessed five times to collect information regarding pain intensity, side effects, and analgesic consumption (Barbosa Neto et al., 2014). Reassessments of pain were scheduled on arrival to Post-Anesthesia Care Unit (PACU), and then at 6, 12, 18 and 24 hours after PCA installation (Barbosa Neto et al., 2014). Based on data collected, it was determined that opioid consumption at 24 hours postoperative was significantly lower in the methadone group than the morphine $(37 \mathrm{mg}$ of methadone use versus 55.6 mg of morphine) (Barbosa Neto et al., 2014). Barbosa Neto et al., (2014) concluded that methadone PCA presented as a favorable drug in the selection of pain management in treating postoperative pain in major surgeries.

\section{Conclusion}

Methadone is a drug that is often stigmatized due to its use in the treatment of substance abuse. Unfortunately, advantageous benefits of the drug are limited in the surgical setting. Methadone is a drug that can offer substantial pain management in the postoperative setting for a wide variety of patients. Although methadone can have varying lengths of duration in individuals, it can offer longer pain management than most opioids used in current practice. For this reason, it can potentially decrease the amount of opioid intake and length of time patients are in pain after surgery. As previously noted, the importance of management of acute postoperative pain can be crucial in preventing severe side effects, such as: increased length of hospital stay, poor healing, increased 
comorbidities, the development of chronic pain, and much more. Methadone should be evaluated for its potential use in the surgical setting in cardiac and thoracic surgeries.

Next, the theoretical framework utilized in this systematic review will be discussed. 


\section{Theoretical Framework}

Healthcare is rapidly growing and frequently changing practice, based on evidence-based data. In order to enhance the delivery of healthcare that Certified Registered Nurse Anesthetists (CRNAs) provide, empirical evidence is examined, proven and converted to standards and guidelines, and placed into practice. Therefore, extracting and evaluating the most relevant evidence available in systematic reviews and meta analyses is required to examine strength and validity. The use of The Preferred Reporting Items for Systematic Reviews and Meta-analyses (PRISMA) statement supports the methods used to search and evaluate the articles used in this systematic review. The PRISMA guidelines were used to improve the quality of data reporting and in the assessment of strengths and weaknesses of each article in the review.

The PRISMA statement (Appendix A) consists of an evidence-based checklist of 27 items that are considered crucial for accurately reporting and evaluating a research study (Daley, 2016). The checklist is divided into categories of sections found in standard research, including: title, abstract, introduction, methods, data collection processes, results, and discussion, bias reporting, limitations, with an additional section providing information regarding funding. After these considerations are met, the articles will then be further investigated for eligibility and omitted if unable to meet previously established inclusion and exclusion criteria. The remaining articles will be utilized for data synthesis and recommendations.

The PRISMA guideline also incorporates a flow diagram that can be used for additional organization of the literature review. The flow diagram allows for transparency 
regarding article selection of inclusion and exclusion criteria. It also allows for guidance among reporting information regarding final number of studies utilized throughout the systematic review. In addition to the PRISMA checklist and flowchart, the consolidated standards of reporting trials framework (CONSORT) are also used (CONSORT, 2011). CONSORT was used to further evaluate and determine quality of the randomized control trials utilized in this systematic review. CONSORT was designed and utilized to assess randomized control trials to evaluate strengths, weaknesses and any limitations to be included, in addition to any research bias.

Next, the methods utilized in this systematic review will be discussed. 


\section{Methods}

\section{Purpose of Study}

The purpose of this paper is to conduct a systematic review to determine if intraoperative methadone administration will affect postoperative pain after cardiothoracic and thoracic surgery as evidenced by pain score levels and documented postoperative opioid use.

\section{Inclusion and Exclusion Criteria}

Inclusion criteria will include: randomized control trials pertaining to subjects 18 years or older; studies evaluating the administration of methadone in a cardiac or thoracic surgery, and evaluation of pain scores postoperatively using pain scales. Exclusion criteria: research before 2004; non-English articles, non-human subjects, and pain management articles not related to methadone use.

\section{Search Strategy}

The literature search was performed using CINAHL and PubMed databases. The initial search was generalized and conducted by using the keyword "methadone" within each database. A total of 5,120 were found utilizing CINAHL and an additional 15,610 articles were located within PubMed. The search was narrowed by the addition of a second keyword: "surgery." The results from both CINAHL and PubMed were drastically reduced to 53 and 542 items, respectively. A final filter was placed to limit the search of literature between the years 2004 and 2019, specifically related to cardiac or thoracic surgery, in addition to filtering the articles to those reporting on adult, human 
subjects only, and written in English. The final search resulted in 23 articles from CINAHL and 80 from PubMed.

\section{Data Collection}

Subsequent to the collection of articles, the randomized control trials (RCT) were reviewed and relevant data was extracted for further analysis. Data was collected from randomized clinical trials in which methadone was given to a portion of the sample population during any part of the operative phase, and later compared opioid use from those who received the methadone versus the control group. As an effort to analyze the influence of methadone on NRS scores in addition to other variables measured in the randomized control trials, a table was created for data collection and comparison of each of the studies. The first table was designed to compare basic, demographic data regarding the groups of patients studied. This included: author, year, number of patients in the study, ages of participants, gender, ASA score, procedure performed, duration of procedure, and allocation of participants into the control and interventional groups (Table 1). 
Table 1

Data Collection Sheet \#1

\begin{tabular}{|l|l|l|l|l|l|l|l|l|l|}
\hline Author, Year & \#Pt & $\begin{array}{l}\text { Ages } \\
\text { (yr) }\end{array}$ & M/F & ASA & Procedure & $\begin{array}{l}\text { Duration } \\
(\mathrm{min})\end{array}$ & $\begin{array}{l}\text { methadone } \\
\text { Group }\end{array}$ & Control Group & Route \\
\hline & & & & & & & & & \\
\hline & & & & & & & & & \\
\hline & & & & & & & & & \\
\hline & & & & & & & & & \\
\hline
\end{tabular}

A second table was created to organize study variables that may have a possible influence over pain scores within each of the trials. Data Collection table \# 2 included author and year, agents used for induction of anesthesia, agents used for the maintenance of anesthesia, timing of administration of the study drug, intraoperative methadone dose administered, intraoperative interventional dose administered, rescue pain medication and dosing used in recovery after surgery, time to first analgesic in each group (Appendix D).

\section{Critical Appraisal}

The critical appraisal tool used to evaluate the randomized control trials in this review was The Consolidated Standards of Reporting Trials, or CONSORT method (Appendix B). The method is a 25-item checklist, utilized to distinguish strengths, weaknesses, limitations and biases of each of the trials. This includes trial design, 
participant eligibility and criteria, setting and location of data collection, interventions administered, outcome measures, sample size determination, randomization, blinding, and funding.

A flow diagram designed by CONSORT, illustrated in figure 1 on the next page, was utilized to assess and determine strength and weaknesses of the randomized control trial. The diagram concentrates on sample size, randomization, allocation of participants and those participants lost during follow up and analysis. The flow diagram was completed for each randomized control trial involved in this systematic review. 


\section{CONSORT \\ TRANSPARENT REPORTING of TRIALS}

CONSORT 2010 Flow Diagram

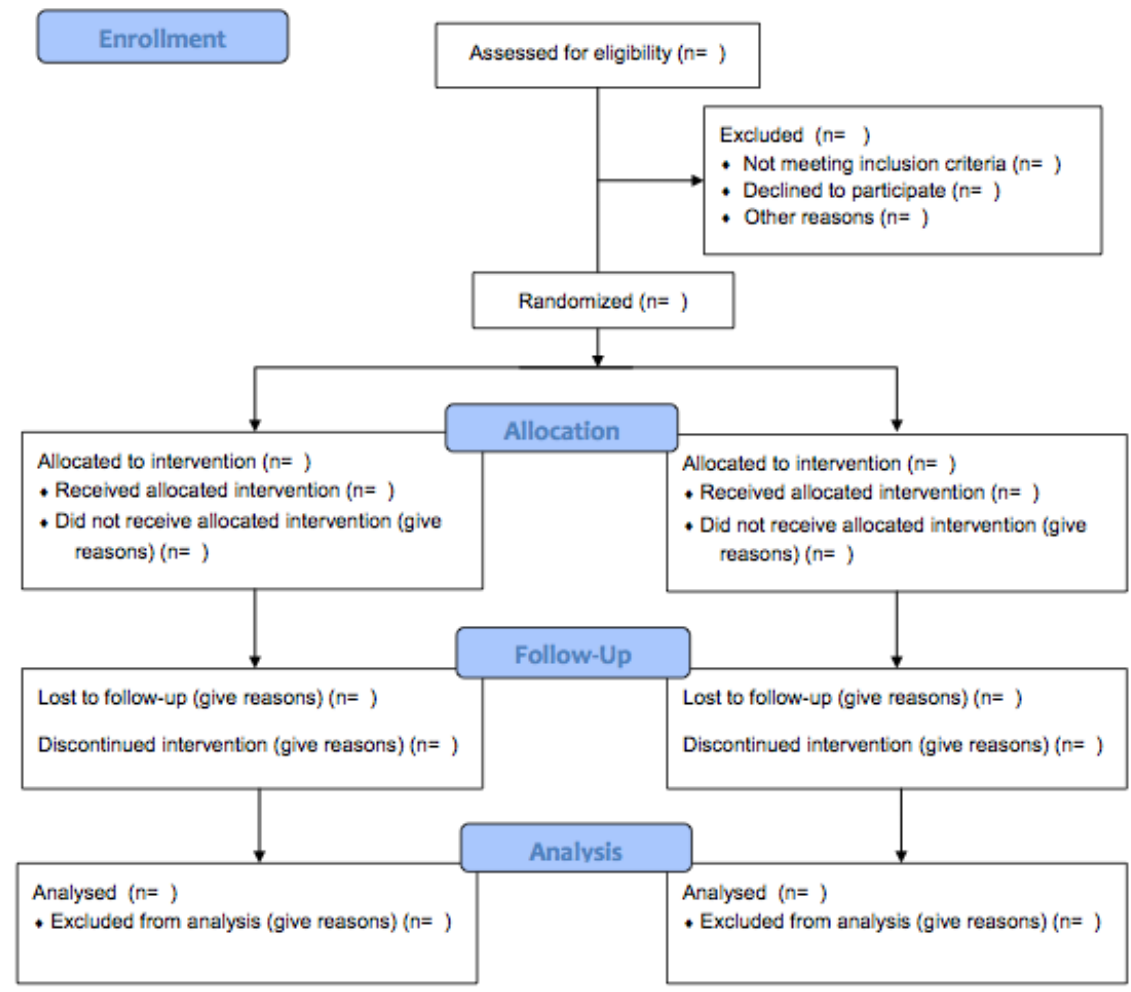

Figure 1. CONSORT Flow Diagram (CONSORT, 2010) 
To best organize the data from the CONSORT findings, a table was created. This table includes: author and year, study type, consent and funding, inclusion and exclusion criteria, randomization, attrition, blinding methods, strengths and limitations of each study (Appendix E). These categories were chosen based on guidelines from both CONSORT and PRISMA checklists and flow diagrams. This method allowed for a more concise and valuable assessment tool.

\section{Data Synthesis and Cross Study Analysis}

The data collection tools that were utilized to derive information from the randomized control trials allowed synthesis and analysis of the data comparatively across each of the studies. A cross study analysis was performed to evaluate the length of surgical duration, time to extubation, time to when the patient needed their first rescue analgesic, the overall NRS scores in the first 24 hours, the extended NRS scores if provided in the study, other and adverse events. The data was transcribed into the table below (Table 2), and the results later described in this paper.

\section{Table 2}

Cross Study Analysis

\begin{tabular}{|c|c|c|c|c|c|c|c|}
\hline $\begin{array}{l}\text { Author, } \\
\text { Year }\end{array}$ & $\begin{array}{l}\text { Surgery } \\
\text { Time } \\
\text { (hr) }\end{array}$ & $\begin{array}{l}\text { Time to } \\
\text { extubation } \\
\text { (hr) }\end{array}$ & $\begin{array}{l}\text { Time to } \\
1^{\text {st }} \\
\text { rescue } \\
\text { analgesic } \\
\text { (hr) }\end{array}$ & $\begin{array}{l}\text { NRS in } \\
\text { first } 24 \\
\text { hrs }\end{array}$ & $\begin{array}{l}\text { NRS } \\
\text { extended } \\
\text { period }\end{array}$ & Other & $\begin{array}{l}\text { Adverse } \\
\text { Events }\end{array}$ \\
\hline & & & & & & & \\
\hline & & & & & & & \\
\hline & & & & & & & \\
\hline & & & & & & & \\
\hline & & & & & & & \\
\hline
\end{tabular}


Next, the results section will be discussed. 


\section{Results}

The PRISMA flow diagram (Appendix E), accompanied by inclusion and exclusion criteria previously mentioned, were used to eliminate and select applicable articles appropriate for this systematic review. After the search for applicable articles and elimination of duplicate articles, a total of 28 articles remained for review. The abstracts of these articles were evaluated for evidence of exclusion criteria. This process eliminated a total of 16 articles. The remaining 12 articles were reviewed thoroughly for their relevance and were selected for the systematic review based on both inclusion and exclusion criteria. The final elimination process excluded 7 articles, leaving 5 articles for inclusion in the systematic review. The five remaining articles were randomized control trials that met the inclusion criteria and were used in the creation of this systematic review. The following information is a summary of results obtained from the data collected.

\section{Cardiac Surgery}

The randomized control trial conducted by Carvalho, Sebold, Calegari, de Oliveria and Schuelter-Trevisol (2011), included 104 patients submitted to coronary bypass graft surgery without cardiopulmonary bypass, age ranging from 53-73 years old and ASA III-IV. The study reported $63 \%$ of patients were males, and additionally reported no proportional difference between groups regarding sex (p-value 0.534 ) (Carvalho et al., 2011). The mean duration of the surgery between the two groups ranged from 187.2-201.1 minutes, with the methadone group mean slightly longer than the morphine group. Four participants were excluded, two from each group for reasons of: 
death, prolonged intubation lasting more than 12 hours and reintubation. This changed the final number of participants to 100 . Induction of anesthesia was performed with sufentanil $0.5 \mathrm{mcg} / \mathrm{kg}$, with $10 \mathrm{mcg}$ boluses as needed, etomidate $0.2 \mathrm{mg} / \mathrm{kg}$ and rocuronium $0.1 \mathrm{mg} / \mathrm{kg}$. Maintenance of anesthesia was achieved with sufentanil 0.25-0.5 $\mathrm{mcg} / \mathrm{kg} / \mathrm{hr}$ and sevoflurane $0.5-1 \mathrm{MAC}$. Patients remained intubated at the end of the procedure upon arrival to ICU. Providers in the ICU were blinded to the group each patient was assigned to. Patients in both groups were given intravenous dipyrone 1 gram every six hours continuously. If patient complained of moderate or severe pain, intravenous morphine $0.03 \mathrm{mg} / \mathrm{kg}$ was administered, with a limit of $0.1 \mathrm{mg} / \mathrm{kg}$ in a fourhour period. If patient complained of nausea or vomiting, metoclopramide hydrochloride $10 \mathrm{mg}$ was administered. Duration of anesthesia, number of doses and types of analgesics and antiemetics were recorded during the postoperative time, along with adverse reactions, such as nausea, vomiting, and respiratory depression. Respiratory depression was defined as a rate of less than 8 respirations per minute, and/or the requirement of reintubation. These reactions were observed by the ICU professionals and/or research team throughout the patient's ICU admission.

Numerical pain scores were recorded at 12, 24 and 36 hours postoperatively. In addition, blinded researchers recorded the first analgesic administration and extubation time. The numerical pain scale was used, with ranges of 0-3 considered mild pain, 4-7 moderate pain and 8-10 severe pain. Mean and standard deviation of pain scores were represented in the study at 12, 24 and 36 hours for both groups. At 12 hours, the morphine group pain score mean was $4.7 \pm 2.6$ and methadone was $4.2 \pm 2.7$. At 24 
hours, morphine scores were $2.9 \pm 2.6$ and methadone $1.9 \pm 2.2$, and at 36 hours morphine $0.5 \pm 1.1$ and methadone $0.5 \pm 1.2$. The time to first analgesic in minutes was $269.4 \pm 252.9$ for the morphine group; the methadone group was shorter, at $149.9 \pm$ 178.5. Although this time was shorter, $43 \%$ of the morphine group required additional postoperative morphine versus $29 \%$ of the methadone group. The morphine group had $19 \%$ adverse events versus the methadone group at $16 \%$. In addition, $27 \%$ of the morphine group required metoclopramide for nausea or vomiting, versus the $18 \%$ of the methadone group. Respiratory failure in each group was similar, $1 \%$ of morphine and $2 \%$ of methadone.

Patients were evaluated for overall satisfaction regarding pain analgesia and occurrence of adverse events in 36 hours. The morphine group reported a $28 \%$ success rate of satisfaction and the methadone group reported $44 \%$ success rate. The study utilized the Kolmogorov-Smirnov test to analyze quantitative, normally distributed data, and the Student's $t$-test to compare means. In non-normal distribution, non-parametric statistics were used applying the Wilcoxon-Mann-Whitney $U$ test. The Pearson chi square test was also used to verify the association between the variables of interest.

Using the CONSORT framework, a flow diagram was presented to assess sample size, eligibility, exclusion criteria, randomization and attrition of the participants in the study (Appendix H-1). The study did not measure level of sedation of patients, which could have had an impact on the patient's level of pain. In addition, pain score medians were recorded at 12, 24 and 36 hours, but information regarding amount of patient assessments, or evaluation of pain scores were not reported. The study also reported 
respiratory failure in each group but did not elaborate on the cause or treatment the patient received. The study reported three patients were excluded prior to initiation of the study due to prolonged extubation time and reintubation. It is unclear by the study if it had an effect on pain scores on either group.

The trial conducted by Udelsman et al. (2011) a group of patients scheduled for cardiac surgery with cardiac bypass, were divided into three groups and given methadone, morphine or a placebo, at induction of anesthesia. The study included 55 patients, ages ranging from 42-72, and ASA III-IV. The study excluded patients on antidepressants, known allergy to study drugs, chronic opioid use, and patients that remained intubated longer than 24 hours after surgery. Information regarding initial pool of patients nor details about the number, nor reason for exclusion of patients was included. Patients were randomly and double blinded into three groups: methadone, morphine and control. Induction on all three groups was performed with sufentanil 0.1 $\mathrm{mcg} / \mathrm{kg}$, midazolam $0.1 \mathrm{mg} / \mathrm{kg}$ and pancuronium $0.1 \mathrm{mg} / \mathrm{kg}$. After induction, each blinded group received a dose of either $20 \mathrm{mg}$ of morphine, $20 \mathrm{mg}$ of methadone or $2 \mathrm{~mL}$ of normal saline. Anesthesia was maintained with sufentanil $0.01 \mathrm{mcg} / \mathrm{kg} / \mathrm{min}$, isoflurane $0.5 \%$ and when clinically indicated, pancuronium $0.03 \mathrm{mg} / \mathrm{kg}$. Patients were transferred to the intensive care unit and continually monitored for pain. After extubation, morphine $0.03 \mathrm{mg} / \mathrm{kg}$ was administered throughout the postoperative period when necessary.

The study evaluated duration of anesthesia, time until extubation, time until administration of the first dose of analgesic, number of doses of analgesics required and prevalence of nausea or vomiting. Time to extubation for each group were as follows: 
methadone $430.83+/ 304.35$, morphine $358.95 \pm 179.15$ and control $341.67 \pm 144.41$. In addition, the time to first analgesic for each group were as follows: methadone $855.17 \pm$ 593.39, morphine $625.53 \pm 525.23$ and control 507.56 \pm 413.04 . The study reported the number of patients requiring analgesics in the first 24 hours was lowest in the methadone group and significantly higher in the control group. Patients requiring analgesic in the first 24 hours was reported in 10 of 18 patients in the methadone group, with a median NRS score of $0.5 \pm 0.71$. The authors of this study reported the number of required doses of pain medication were $0.89 \pm 1.02$. Comparatively, 14 of the 19 patients in the morphine group required $1.32 \pm 1.05$ doses with a median NRS of $1.84 \pm 1.38$. The control group required $2.39 \pm 0.85$ doses with median NRS $2.83 \pm 2.18$. The number of patients reporting postoperative nausea or vomiting (PONV) were 1 of 18 patients in the methadone group, 6 of 19 patients in the morphine group and 9 of 18 in the control group.

A CONSORT flow diagram (Appendix H-2) was used to report data regarding sample selection, allocation and attrition. The researchers did not report the initial number of participants assessed for the study. Although the researchers did mention patients that were intubated longer than 24 hours in the postoperative period were excluded from the study, it did not report the number of participants that were excluded for this reason. A total of 55 patients were included in the study.

Murphy et al. (2015) conducted a randomized control trial of patients undergoing elective cardiac surgery with cardiopulmonary bypass that were randomized to receive intravenous methadone or fentanyl intraoperatively. The study included 156 patients, age 
ranges 54-75, both groups with a higher percentage of male participants. Height and weight of each group was within a similar range, and ASA scores were III-IV. Four options for surgery existed: coronary artery bypass graft $(\mathrm{CABG})$, valve surgery, $\mathrm{CABG}$ with valve surgery or atrial septal defect repair. The induction and maintenance of anesthesia was treated the same regardless of surgery performed.

Patients were randomized by a computer-generated randomization code to receive either methadone or fentanyl intraoperatively. The study opioid was prepared by the operating room pharmacy in identical appearing clear plastic bags, and doses were reported as equipotent. Induction of anesthesia was induced with midazolam 2-4 mg, propofol 20-100 mg titrated to loss of consciousness, and rocuronium $0.6-0.8 \mathrm{mg} / \mathrm{kg}$. At the time of the induction, one half of the study drug was administered via an infusion pump over 5 minutes. The remainder of the drug, methadone $0.15 \mathrm{mg} / \mathrm{kg}$ or fentanyl 6 $\mathrm{mcg} / \mathrm{kg}$, was infused over the following two hours. Maintenance of anesthesia was with sevoflurane $0.4-3 \%$, titrated to Bispectral Index values of 40-60 and to mean arterial pressure within $20 \%$ of baseline value. During rewarming phase of the surgery, midazolam $5 \mathrm{mg}$ was administered, and during chest closure an infusion of propofol 10$50 \mathrm{mcg} / \mathrm{kg} / \mathrm{min}$ was started and continued until ventilatory weaning in the ICU. Time of ventilatory weaning in the ICU was comparable of both groups, methadone group at mean of 4.75 hours and fentanyl group of 4.5 hours. Extubation time was 6.5 and 6.0 hours, respectively. The study did note that the methadone group did have a quicker ICU discharge to the surgical ward, a mean of 30.5 hours, versus the fentanyl group at 47.1 hours. 
Patients were assessed for pain at rest and with coughing by nurses in the ICU after discontinuation of the propofol infusion and extubation, and then every 2 hours after. If pain was reported of higher than mild severity, morphine $2 \mathrm{mg}$ was administered, with additional doses until patient reported a verbal pain score less than 3 . Oral pain management was transitioned once the patient was discharged from the ICU to the surgical ward, which consisted of one hydrocodone-acetaminophen 10/325 mg tab for mild pain, and two tabs for moderate pain. Once on the surgical ward, patients' pain scores were evaluated every four to six hours and morphine or oral pain management was administered as needed.

In the initial 15 minutes in recovery, patients in the methadone group reported a median pain score of 3 , versus the fentanyl group at 5 ( $\mathrm{p}$ value $<0.001$ ). At two hours, the methadone group reported a median of 3 at rest and 4 with coughing, and the fentanyl group reported median of 4.5 and 7 , respectively $(\mathrm{p}<0.001)$. At 12 hours, the methadone group reported pain score median of 2, 4 with coughing, and in the fentanyl group, 4 and 6 respectively. Median pain scores at 24, 48 and 72 hours at rest in the methadone group was 2 for each time, and with coughing: 5 at 24 hours and 4 at 48 and 72 hours. As comparison, in the fentanyl group, the median scores at rest were 4 at 24 hours and 3, at 48 and 72 hours, and with coughing 7 at 24 hours, 6 at 48 hours and 5 at 72 hours. Overall satisfaction of pain management was also collected at these times using the VAS and ranged from 90-100 in the methadone group, and in the fentanyl group ranged from $70-90$. 
Opioid related complications were reported as nausea, vomiting, itching, hypoventilation, hypoxemia and sedation. In the methadone group, nausea was reported in $50 \%$, vomiting $24 \%$, itching $22 \%$, hypoventilation $4 \%$, hypoxemia $13 \%$ and sedation $83 \%$. In the fentanyl group, nausea was reported in $56 \%$, vomiting $19 \%$, itching $12 \%$, hypoventilation $4 \%$, hypoxemia $8 \%$ and sedation $90 \%$.

Murphy et al. (2015) reported decreased morphine requirements in the first 24 hours after cardiac surgery and improved pain scores 12 hours after extubation, summarized in median and interquartile ranges. These variables were compared between both randomized groups utilizing the Mann-Whitney $\mathrm{U}$ test and median differences and their 99\% Cis were calculated. Murphy et al. (2015), concluded that intravenous morphine requirements during the first 24 hours after surgery and total doses of postoperative morphine were reduced by $40 \%$ in the methadone group. They reported that nearly one third of the patients in the fentanyl group required high dose morphine, defined by greater than $20 \mathrm{mg}$, for pain control in the first 24 hours. This was compared to the $2.5 \%$ of patients in the methadone group that required high dose morphine in the postoperative period. Additionally, the five patients that did not require morphine 24 hours postoperatively were all from the methadone group.

A few limitations were noted within the study conducted by Murphy et al. (2015). Although a safe and effective dose of methadone was used intraoperatively for the purpose of this study, the most optimal methadone dose was not determined. Additionally, the pain scale was only reported until 72 hours postoperative, and high risk cardiac patients were excluded from enrollment of the study. 
The study conducted by Murphy et al. (2015) reported participant inclusion and exclusion criteria, and the number of patients assessed for the study. A CONSORT chart (Appendix H-3) was created to evaluate the sample selection, allocation and attrition of the study. Eight patients were excluded before completion of the ICU data collection due to protocol violations, study drug unavailable at start of surgery, canceled surgery due to calcified aorta, and patient death after ICU arrival. A large sample size of 156 participants completed the study and were included in the final analysis.

\section{Thoracic Surgery}

Matot, Drenger, Weissman, Shauli and Gozal (2004) conducted a study using clonidine, bupivacaine and methadone as sole analgesics for patients undergoing a thoracotomy for lung resection. The study evaluated 47 patients undergoing a lung resection and treated postoperatively for 72 hours with one of the study drugs. One of the main objectives of this study was to evaluate lung function and evaluated spirometry throughout the study, along with pain management. For purposes of this systematic review, pain scores will be the only reported values.

Patients were premedicated with diazepam $10 \mathrm{mg}$ orally, one hour prior to the procedure. In the operating room, an epidural catheter was placed at either T4-T5 or T5T6 intervertebral space with $4 \mathrm{~cm}$ of catheter in the epidural space. A $3 \mathrm{~mL}$ test dose of lidocaine $2 \%$ with epinephrine $(1: 200,000)$ was administered, followed by $10 \mathrm{~mL}$ of bupivacaine $0.25 \%$. Correct placement of the catheter was confirmed by a sensory loss of cold sensation above T4. A minimum of 20 minutes elapsed before start of surgery to allow for achievement of effect. General anesthesia was then induced with Propofol 2 
$\mathrm{mg} / \mathrm{kg}$, fentanyl $2 \mathrm{mcg} / \mathrm{kg}$ and vecuronium $0.1 \mathrm{mg} / \mathrm{kg}$. Maintenance of anesthesia was achieved with isoflurane in a 50\% oxygen-nitrous oxide mixture. Additional doses of fentanyl $1.5 \mathrm{mcg} / \mathrm{kg}$ were administered when mean arterial pressure or heart rate increased 25\% from the baseline value. Additional boluses of vecuronium were administered when clinically required.

During skin closure, patients were selected and placed into a double blinded group to receive one of the three study drugs for postoperative analgesia. Patients in the clonidine group received an initial dose of clonidine $8 \mathrm{mcg} / \mathrm{kg}$ in $10 \mathrm{~mL}$ of saline over 20 minutes, followed by an infusion of $1 \mathrm{mcg} / \mathrm{kg} / \mathrm{hr}$. Patients in the bupivacaine group received an initial dose of $10 \mathrm{~mL}$ of $0.25 \%$ bupivacaine over 20 minutes, followed by an infusion of $0.125 \%$ bupivacaine. Patients in the methadone group received an initial dose of $6 \mathrm{mg}$ of methadone in $10 \mathrm{~mL}$ of normal saline over 20 minutes, followed by an infusion of $0.5 \mathrm{mg} / \mathrm{hr}$. The maintenance infusion of each group ran during the first 72 hours postoperatively and pain scores were recorded at $8,24,48$ and 72 hours. On a numerical pain scale from $0-10$, if pain scores were greater than or equal to a 3 at rest, or 4 with coughing, patients were given diclofenac $75 \mathrm{mg}$, a nonsteroidal anti-inflammatory drug (NSAID), intramuscularly.

Matot et al. (2004) reported pain scores determined by the NRS were not statistically significant throughout the study period. The study reported in all groups, pain was significantly lower at 72 hours compared to those at 8 and 24 hours. By the third day, the bupivacaine group required more diclofenac than the clonidine or methadone groups to achieve pain scores lower than 3 at rest or 4 with coughing. The bupivacaine group 
required $575 \mathrm{mg}$ (standard deviation 115), clonidine $325 \mathrm{mg}$ (SD 90) and methadone group $300 \mathrm{mg}$ (SD 120). The study recorded adverse side effects, including pruritis, vomiting, hypotension, bradycardia, weakness or numbness of limbs, urinary retention and sedation. Methadone was the only group in which 3 patients, or $21 \%$, reported pruritis. Each group reported vomiting, $6 \%$ in the clonidine group, $12 \%$ in the bupivacaine group and $28 \%$ in the methadone group. Hypotension and bradycardia were not noted in the methadone group. Hypotension occurred in both $24 \%$ of the clonidine and bupivacaine groups, and bradycardia only occurred in $12 \%$ of the clonidine group. Weakness or numbness of limbs was reported in $12 \%$ of the bupivacaine group and in neither of the methadone or clonidine group. All groups reported urinary retention. Sedation was reported in $18 \%$ of the clonidine group, $0 \%$ of the bupivacaine group, and $14 \%$ of the methadone group.

The study conducted by Matot et al. (2004) demonstrated pain scores on the NRS were not statistically significant between the groups throughout the study period. By the third postoperative day, it was reported the bupivacaine group required slightly more diclofenac to achieve pain scores less than or equal to 3 at rest, or 4 with coughing. A few limitations existed within the study. One limitation of the dose of clonidine was selected based on previous reports of clonidine usage in controlling postoperative pain. The dose selected for this study was based on previous studies concluding that higher doses caused excessive patient sedation and hemodynamic instability, which were two variables studied and reported. The study also lacked a placebo group, and reported on small, unequal populations within each group. 
A CONSORT flow diagram was created for this study to collect data reported regarding sample selection, allocation and attrition rates (Appendix H-4). The study did not provide information regarding the 7 patients that were excluded due to intraoperative reasons. There were no participants lost to analysis or follow up after the initial selection and randomization of treatment groups.

Perez et al. (2007) evaluated epidural methadone for acute post thoracotomy pain versus ropivacaine with fentanyl. The study was a prospective, randomized, open labeled clinical trial that compared two epidural analgesic regimens. Patients scheduled for an elective thoracotomy for lung resection surgery, age range 54-61, ASA II-III. A total of 49 patients over a 4-month period were included in this study.

Preoperative anesthetic management included midazolam (dosage not specified). Before induction of general anesthesia, an epidural catheter was placed at T8-9 intervertebral space and a test dose of $4 \mathrm{~mL}$ of $2 \%$ lidocaine with adrenaline was administered. General anesthesia was induced with propofol, fentanyl, and rocuronium. Maintenance of anesthesia included propofol, remifentanil and rocuronium. Dosages for drugs during both phases were not reported. Postoperative analgesia was initiated on chest closure with $5 \mathrm{~mL}$ of ropivacaine $0.5 \%$. Patients were randomized to two groups, patient controlled epidural analgesia (PCEA) and epidural methadone. The PCEA group received a continuous infusion of $0.16 \%$ ropivacaine plus fentanyl $3.5 \mathrm{mcg}$ at a continuous rate of $6-10 \mathrm{~mL} / \mathrm{hr}$, along with a patient controlled, self-administration dose of $4 \mathrm{~mL}$ boluses with a lockout interval of 20 minutes between each bolus. The epidural methadone group received boluses every 8 hours of 4-6 mg preservative free $0.1 \%$ 
methadone, based on a formula including patients weight and age. Both groups received intravenous ketorolac $30 \mathrm{mg}$ every 8 hours, and rescue analgesia included propacetamol four times daily when pain at rest was reported equal to, or above a 3 on the NRS. Epidural analgesia was administered to the PCEA group over $3.3 \pm 0.1$ days and $3.7 \pm 0.2$ days in the methadone group.

Pain scores were taken at 1, 2, 6, 12, 24 and 48 hours after the procedure. Initially, $69.6 \%$ of the methadone group requested rescue analgesic at 1 hour versus $44 \%$ in the PCEA ropivacaine with fentanyl group. However, patients in the PCEA group requested more rescue analgesia during the first 24 and 48 hours compared to the methadone group. At 24 hours, $32 \%$ of the PCEA group requested rescue analgesia versus $8.7 \%$ in the methadone group, and at 48 hours, $28 \%$ versus $0 \%$ respectively, requested rescue analgesia. Secondary effects, sedation, hypotension, motor blockade, vomiting and pruritis were recorded for each group. Sedation, hypotension, vomiting and pruritis were reported at 1 hour and two reports were given for 24 hours, some with different values. In the methods section, the authors report secondary adverse effects were recorded during the first 48 hours. It is unclear if the author made a mistake and mislabeled the time reported in the secondary effects table. No other secondary effects at 48 hours are reported within the article. The following information is reported as it has been reported in the study. Sedation scores in the PCEA group were $28 \%$ at 1 hour, $0 \%$ at 24 hours and $4 \%$ at 24 hours in the PCEA group, and $39.1 \%, 13 \%$ and $15 \%$ in the methadone group, respectively. Hypotension ranged from 0-28\% through the 1-24 hours in the PCEA group, and $0-8.7 \%$ in the methadone group. Neither group reported a prolonged motor 
blockade during any interval postoperatively. Vomiting in the PCEA group ranged from $0-12 \%$ in 1 hour to 24 hours postoperatively versus methadone which sustained $13 \%$ through all periods. Less than 5\% of pruritis was reported in the PCEA group and $4.3 \%$ was reported in the methadone at 24 hours, but was not reported during other intervals. A telephone survey was carried out four months after the procedure to evaluate for chronic pain. Two patients from the PCEA group reported persistent thoracic pain and 1 from the methadone group. Researchers concluded a total incidence of $6.1 \%$ prevalence of chronic postoperative chronic pain was found.

The CONSORT flow diagram was used to report sample selection, allocation and attrition (Appendix H-5). There were no reports of patients excluded from the study or loss of participants during the study. Limitations included small sample size and ambiguous data regarding interval of recording. Although drugs were administered via the same epidural route, they were on different time intervals and patients in the PCEA group received a continuous infusion and had the option to self-administer a dose when they felt necessary, versus the methadone group that received bolus dosage every eight hours.

\section{Cross Study Analysis}

The randomized control trials used for this systematic review were analyzed across studies utilizing data extracted and organized in the data collection sheet previously shown in Table 2 . This tool was used to record and analyze surgery time, time to extubation, time to first rescue analgesic, NRS score in the first 24 hours, NRS over 
the length of time the study evaluated pain, reported rescue drug use and adverse events (Appendix I).

Mixed results regarding the efficacy and improvement in pain scores and adverse reactions to methadone treatment throughout the perioperative period were presented through cross study analysis of the studies involved in this systematic review. The study conducted by Murphy et al. (2015) (Appendix I) significant reduction in postoperative NRS scores and opioid use was noted within the methadone group compared to the fentanyl group. Initial time to first rescue analgesic dose in the methadone group ranged from 3.25-9.25 hours, versus the fentanyl group requiring analgesia much sooner, at 1.55.75 hours. Pain scores at rest were significantly less in the methadone group than the fentanyl group throughout the first 72 hours $(P<0.001$ to 0.002$)$. Similarly, pain scores while coughing were less in the methadone group than in the fentanyl group throughout the first 3 postoperative days (all $P<0.001$ ). Intravenous morphine requirements in the methadone group were reduced by $40 \%$ during the first 24 hours postoperatively and reported a higher patient perceived quality of pain management. Perez et al. (2007) (Appendix I) found epidural methadone had a reduction in rescue analgesia in the methadone group versus PCEA ropivacaine with fentanyl group. Although the study found that rescue analgesia at 1 hour was increased in the methadone group, it was significantly decreased at 24 and 48 hours. The percentage of patients that requested doses of rescue analgesia was reported as $8.7 \%$ and $0 \%$ at 24 and 48 hours in the methadone group, and in the PCEA group $32 \%$ and $28 \%$, respectively $(P<0.05)$. Matot et al. (2004) reported a significant difference $(P<0.05)$ in pain scores among participants 
that received clonidine, bupivacaine and methadone for postoperative thoracotomy pain. The study reported little significance between the three drugs but did note the participants in the bupivacaine needed significantly more rescue analgesia to achieve lower scores when compared to the clonidine and methadone groups.

Lastly, in the two studies by Carvalho et al. (2011) and Udelsmann et al. (2011) both compared methadone to morphine and found methadone superior in the management of postoperative pain relief. Carvalho reported a methadone efficacy $22 \%$ higher than that of morphine, with pain scores lower at 12 and 24 hours postoperative, $(p=0.186)$ and $(p=0.029)$. Udelsmann reported the first dose of analgesic in the methadone group was requested after a longer period of time $(\mathrm{p}=0.0261)$. In addition, the number of patients that required analgesics was significantly lower in the methadone group $(\mathrm{p}=0.025)$ and the quality of analgesia was improved in the methadone group $(\mathrm{p}<$ $0.01)$.

Adverse events reported among all of the studies included nausea, vomiting, respiratory failure, sedation, hypotension, bradycardia, pruritis, hypoventilation, and hypoxemia. Nausea and/or vomiting or described as postoperative nausea and vomiting (PONV), were among the most common side effects throughout all studies in both the methadone and intervention groups. Data regarding these side effects were similar across all studies comparing methadone to other opioids such as morphine and fentanyl.

Udelsmann (2011) did show the incidence of PONV was significantly lower than in the methadone group versus the other two groups $(\mathrm{p}=0.013)$.

Next, summary and conclusions section will be presented. 


\section{Summary and Conclusions}

Pain plays a significant role of the perioperative period and is much anticipated after surgery. Patients often express postoperative pain as a major concern, with uncontrolled pain being a primary fear (Hutchinson, 2007). As a result, postoperative pain control is a primary goal for patients and providers. Persistent acute pain is associated with increased risk of morbidity, impairment of functionality and quality of life, delays in recovery, increased financial burden and prolonged opioid usage (Gan, 2017). Health risks such as impaired mobilization, deep vein thrombosis, pneumonia, respiratory failure, pulmonary embolism and wound infections can further spiral into negative consequences that can relate to increased morbidity and mortality (Hutchinson, 2007). Furthermore, prolonged acute pain can lead to the development of chronic pain, which can contribute to disability, depression, reduced quality of life, morbidity and mortality (Gan, 2017). Management of pain throughout the perioperative period is crucial to successful management of the surgical patient. The purpose of this paper is to conduct a systematic review to determine if intraoperative methadone administration will affect postoperative pain after cardiothoracic and thoracic surgery as evidenced by pain score levels and documented postoperative opioid use.

A literature review was conducted utilizing a table with inclusion and exclusion criteria created by the author. The PRISMA checklist (Appendix A) was used to review each article prior to selection. The PRISMA flow diagram was then used to assist in the organization and collection of data from the literature search (Appendix F). A total of five randomized control trials were selected. The randomized control trials were further 
critiqued using the CONSORT checklist (Appendix B) to evaluate strength and significance of the studies discussed in this systematic review. Data was collected from each of the articles and information was recorded within tables created by the author (Appendix C). Information drawn from each study included author, publication year, number of patients in the trial, age of participants, gender, ASA score, procedure, duration, methadone group, control group and route of drug administration, agents used for induction of anesthesia, agents for maintenance of anesthesia, administration time of study drug, intraoperative dose of methadone, intraoperative control dose, recue pain dosing, time to first rescue analgesic for methadone group, time to first rescue analgesic for control group (Appendix G-1, 2). Strengths and weaknesses from each study were recorded in a separate table created by the author of this review using the criteria published from the CONSORT checklist (Appendix G-3). With the focus on sample size, randomization and attrition rates of participants for each randomized control trial, a PRISMA flow diagram was completed for each study (Appendix H-1, 2, 3, 4, 5). Analysis across the studies was completed utilizing the chart in Appendix I. This chart recorded the surgical time, time to extubation, time to first rescue analgesic, the numerical rating scale (NRS) score in the first day, the NRS score in extended periods, reported rescue drug use and adverse events.

Three of the studies reported the amount of time that passed until the patient required their first rescue analgesic in each of the groups. Carvalho et al., (2011) reported that the rescue dose of analgesia was required sooner in the methadone group than in the morphine group. (Appendix G-2). Udelsman et al., (2011) and Murphy et al., (2015), 
reported time to first rescue analgesic was much more delayed in the methadone group in each of their studies versus the control group (Appendix G-2). With the exception of Matot (2004), which reported no clinical significance between the three drugs studied, the other four studies showed that the patients in the methadone group reported overall lower pain scores on the NRS scale in the first 24 hours (Appendix I). Reports of pain scores later than 24 hours postoperative were not reported in two of the studies. In the trial conducted by Carvalho et al., (2011), pain scores were similar in both groups at 36 hours postoperatively. Murphy et al., (2017), reported slight improvement in pain scores in the methadone group at 72 hours postoperative (Appendix I). Perez et al., (2007), reported no additional pain management requirements at 48 hours postoperative in the methadone and $28 \%$ of patients requesting additional pain management in the ropivacaine plus fentanyl group (Appendix I).

Adverse effects noted from the drugs were recorded in all five of the studies presented. The most commonly presented side effect of the drugs were postoperative nausea and vomiting (PONV). Of the studies that compared other opioids, such as morphine to methadone, the data regarding PONV was similar. Nausea with vomiting ranged from $5-28 \%$ of patients and was not highly significant based on the opioid the patient was given. Other side effects reported included pruritis, respiratory failure, hypoxemia, hypoventilation, sedation, hypotension, bradycardia, urinary retention, and limb weakness (Appendix I).

Limitations existed in this systematic review. Although studies included in this review fulfilled the inclusion criteria, the inclusion of five randomized control trials with 
relatively small sample sizes may decrease the generalizability of this study. Additionally, the review may have been more generalizable if all participants had the same surgical procedure, same control drug and if the drug was given by the same route in each study. The rescue drug in two of the trials by Carvalho et al. (2011) and Udelsmann et al. (2011) used morphine as the control drug and also as the rescue analgesic. This may have affected the strength of the results.

Diversity varied greatly among the five randomized control trials and may have contributed to a weakened conclusion of the study. Each study administered the methadone and control drug at different time intervals during the operation and by different routes. Some studies administered the drug after induction of anesthesia, while Murphy et al. (2015) administered half after induction and then the other half over the following two hours. Carvalho et al. (2011) administered the drug at the end of the surgery, but did not specify when, while Matot et al. (2004) administered the drug during skin closure and Perez et al. (2007) administered at the closure of the chest cavity. Four of the five studies administered the drug intravenously, and one administered the drug via epidural route. Although each study reported the overall NRS scores in the first 24 hours after drug administration, some studies failed to record NRS scores further than 24 hours. This potentially could have weakened the conclusions of the study, as methadone halflife can range greatly among individuals and exert a prolonged effect up to 90 hours (Barbosa Neto, et al., 2014). Additionally, the studies reported by Matot et al. (2004) and Perez et al. (2007) did not document the time of the first requested rescue analgesic after the methadone or control drug was administered (Appendix G-2). 
Due to the many limitations, this systematic review does not provide sufficient evidence to implicate the use of methadone as an effective means to decrease postoperative pain after thoracic surgery. Recommendations and implications for advanced nursing practice will be discussed in the next section. 


\section{Recommendations and Implications for Advanced Nursing Practice}

Advanced Practice Registered Nurses (APRNs), including Certified Registered

Nurse Anesthetists (CRNAs) rely on evidence-based research to care for patients.

Systematic reviews are frequently reviewed to evaluate a large sum of information

throughout multiple published studies to present recommendations for best practice. This

supports safe practice and the most up to date knowledge informing the anesthesia

community. CRNAs provide anesthesia to patients undergoing cardiothoracic or thoracic

surgery until the procedure is completed and the patient is transported to their respective

recovery areas and care is designated to the registered nurse in the Post Anesthesia

Recovery Unit (PACU) or Intensive Care Unit (ICU). Treatment of pain throughout a

procedure or surgery is important not only during the procedure, but for the prevention of pain upon their arrival and stay in the PACU or ICU.

The delivery of anesthesia is often defined as the combination of both science and art. Ability to provide anesthesia is achieved through extensive training in both classroom and surgical settings with a focus on the delivery of safe, effective and appropriate anesthesia. Continued education and reviewing current research is crucial for the anesthesia provider and the safety of their patients. Systematic reviews, such as this one, are intended to review multiple research articles and extract information that may be useful to better serve the surgical population undergoing anesthesia. It allows for CRNAs to consider the most up to date, safest and most effective methods of providing anesthesia. 
One of the most important factors in providing an effective anesthesia involves the treatment of pain. Prevention and treatment of pain is often discussed and disputed due to the multiple options for pain management. Methadone is often stigmatized due to its use in opioid addiction treatment programs. It is also often used in the treatment of chronic pain, especially in patients with cancer. The use of methadone within the operating room for standard procedures is not widely discussed nor used. The purpose of this paper is to conduct a systematic review to determine if intraoperative methadone administration will affect postoperative pain after cardiothoracic and thoracic surgery as evidenced by pain score levels and documented postoperative opioid use.

The use of methadone during the perioperative phase of cardiothoracic and thoracic surgery in this systematic review had mixed results. As noted on Appendix I, the NRS scores were not significantly different across all of the studies in the methadone group. However, utilizing methadone in the surgeries specific to cardiothoracic, slight improvements in pain scores were noted. This may present a need for future randomized control trials to evaluate the use of methadone pertaining specifically to cardiothoracic surgery. Future studies may be performed comparing methadone and morphine, with the recommendation of a rescue drug being different than the one utilized as a control drug, as most of these studies used morphine in the intraoperative and postoperative pain management. These studies would be essential to evaluate the most effective management of pain in the population of thoracic surgical patients. 


\section{References}

Apfelbaum, J.L., Chen, C., Mehta, S.S, \& Gan, T.J. (2003). Postoperative pain experience: results from a national survey suggest postoperative pain continues to be undermanaged. Anesthesia \& Analgesia 97(2). 534-40.

Barbosa Neto, J., Tavares Machado, M.D., de Almedia Correa, M., Alves Scomparim, H., Posso, I. P., \& Ashmawi, H.A. (2014). Methadone patient-controlled analgesia for postoperative pain: a randomized, controlled, double-blind study. Journal of Anesthesia, 28(4), 505-510. doi10.1007s00540-013-1785-3

Bayman, E.O., Parekh, K.R., Keech, J., Setle, A., \& Brennan, T.J. (2017). A Prospective Study of Chronic Pain after Thoracic Surgery. Anesthesiology, 126(5). 938-951.

Bignami, E., Castella, A., Pota, V., Saglietti, F., Scognamiglio, A., Trumello, C., ... Allegri, M. (2018). Perioperative pain management in cardiac surgery: a systematic review. Minerva Anestesiologica,84(4).488-503.DOI: $10.23736 / \mathrm{S} 0375-9393.17 .12142-5$

Carr, D.B., \& Goudas, L.C. (1999). Acute Pain. The Lancet, 353, 2051-2058.

Carvalho, A.C., Sebold, F.J.G., Calegari, P.M.G., de Oliveria, B.H., \& SchuelterTrevisol, F. (2018). Comparison of postoperative analgesia with methadone versus morphine in cardiac surgery. Revista Brasileira de Anestesiolgia, 68(2), 122-127.

Chou, R., Gordon, D.B., de Leon-Casasola, O.A., Rosenberg, J.M., Bickler, S., Brennan, 
T., C... Wu, C.L. (2016). Guidlelines on the Management of Postoperative Pain. The Journal of Pain, 17(2), 131-157. Retrieved from:

https://www.jpain.org/article/S1526-5900(15)00995-5/fulltext

CONSORT (2010). www.consort-statement.org

Daley, D. (2016). Meta-analyses: Merits, Limitations, and Application of the PRISMA

Statement. AMWA Journal. 31(1). 12-19. DOI: 10.23736/S0375-9393.17.12142-5

Dijk, J.M., Kappen, T.H., Schuurmans, M.J., \& Wijck, A.M. (2015). The Relation Between Patients' NRS Pain Scores and Their Desire for Additional Opioids after Surgery. Pain Practice, 15(7), 604-609. Doi:10.1111/papr.12217

Gan, T. (2017). Poorly controlled postoperative pain: prevalence, consequences, and prevention. Journal of Pain Research. 2017(10). 2287-2298. http://dx.doi.org/10.2147/JPR.S144066

Glowacki, D. (2015). Effective Pain Management and Improvements in Patients' Outcomes and Satisfaction. Critical Care Nurse, 35(3). 33-41. DOI: $10.4037 / \operatorname{ccn} 2015440$

Gottschalk, A., Cohen, S.P., Yang, S., \& Ochroch, E.A. (2006). Preventing and Treating Pain after Thoracic Surgery. Anesthesiology. 104(3). 594-600.

Gottschalk, A., Durieux, M. E., \& Nemergut, E. C. (2011). Intraoperative Methadone Improves Postoperative Pain Control in Patients Undergoing Complex Spine Surgery. Anesthesia \& Analgesia, 112(1), 218223.doi:10.1213/ANE.0b013e3181d8a095 van Gulik, L., Janssen, L.I., Ahlers, S.J.G.M., Bruins, P., Driessen, A.H.G., van Boven, 
W.J., ... Knibble, C.A.J (2011). Risk factors for chronic thoracic pain after cardiac surgery via sternotomy. European Journal of Cardio-thoracic Surgery, 40(2011). 1309-1313. Retrieved from https://academic.oup.com/ejcts/article$\underline{\operatorname{abstract} / 40 / 6 / 1309 / 418277}$

Guastella, V., Mick, G., Soriano, C., Vallet, L., Escande, G., Dubray, C., \& Eschalier, A. (2011). A prospective study of neuropathic pain induced by thoracotomy: Incidence, clinical description and diagnosis. Pain, 152(1), 74-81. Doi:10.1016/j.pain.2010.09.004

Hall, M.J., Schwartzman, A., Zhang, J., \& Liu, X. (2017). Ambulatory Surgery Data From Hospitals and Ambulatory Surgical Centers: United States, 2010. Centers for Disease Control and Prevention National Center for Health Statistics, 102, 114. Retrieved from https://www.cdc.gov/nchs/data/nhsr/nhsr102.pdf

Helms, J. E., \& Barone, C. P. (2008). Physiology and treatment of pain. Critical Care Nurse, 28(6), 38-49. Retrieved from http://ccn.aacnjournals.org/content/ 28/6/38.full.pdf + html

Hutchinson, R.W. (2007). Challenges in acute postoperative pain management. $A M J$ Health-System Pharm, 64(4). 52-55. International Association for the Study of Pain. (2017). https://www.iasppain.org/index.aspx

International Association for the Study of Pain (2011). Pain. International Association for the Study of Pain. Retrieved from http://www.iasppain.org/AM/Template.cfm?Section=Pain_Definitions IOM (Institute of Medicine). (2011). Relieving Pain in America: A Blueprint for 
Transforming Prevention, Care, Education, and Research. Washington, DC: The National Academies Press.

Jafra, A., \& Mitra, S. (2018). Pain relief after ambulatory surgery: Progress over the last decade. Saudi Journal of Anaesthesia, 12(4), 618-625. https://doiorg.ric.idm.oclc.org/10.4103/sja.SJApass:[ ] $232 \_18$

The Joint Commission. (2017). The Joint Commission Perspectives. The Official Newsletter of The Joint Commission, 37(7). 1-4. www.jointcommission.org The Joint Commission. (2018). The Joint Commission Fact Sheet. The Joint Commission. https://www.jointcommission.org/assets/1/18/The Joint_Commission_Fact_Sheet $7 \quad 2 \quad 18 . p d f$

Kehlet, H., Jensen, T.S., \& Woolf, C.J. (2006). Persistent postsurgical pain: risk factors and prevention. Lancet, 367(9522), 1618-1625. doi:10.1016/S01406736(06)68700-X

Kharasch, E. D. (2011). Intraoperative methadone: Rediscovery, reappraisal, and reinvigoration? Anesthesia and Analgesia, 112(1), 12-16. doi:10.1213/ANE.0b013e3181fec9a3

Kliger, M., Stahl, S., Haddad, M., Suzan, E., Adler, R., \& Eisenberg, E. (2015). Measuring the Intensity of Chronic Pain: Are the Visual Analogue Sale and the Verbal Rating Scale Interchangeable? Pain Practice, 15(6), 538-547. Doi: 10.1111/papr.12216

Kuo, I., Chang, K., Juan, D., Hsu, S., Chan, C., \& Tsou, M. (2018). Time-dependent 
analysis of dosage delivery information for patient-controlled analgesia services. Plos ONE, 13(3), 1-13. Doi:10.1371/journal.pone.0194140

Matot, I., Drenger, B., Weissman, C., Shauli, A., \& Gozal, Y. (2004). Epidural clonidine, bupivacaine and methadone as the sole analgesic agent after thoracotomy for lung resection. Anaesthesia, 59, 861-866.

Moher, D., Liberati, A., Tetzlaff, J., \& Altman, D. (2009). Preferred reporting items for systematic reviews and meta-analyses: The PRISMA statement. PLoS Medicine, 6(7), 1-6. doi:10.1371/journal.pmed.1000097

Murphy, G.S., Szokol, J.W., Avram, M.J., Greengerg, S.B., Marymont, J.H., Shear,T., ... Gupta, D.K. (2015). Intraoperative Methadone for the Prevention of Postoperative Pain: A Randomized, Double-blinded Clinical Trial in Cardiac Surgical Patients. Anesthesiology, 122(5), 1112-1122.

Nagelhout, J.J., \& Plaus, K.L. (2014). Nurse Anesthesia. St.Louis, MO: Elsevier.

Pacreu, S., Candil, J.F., Molto, L., Carazo, J., \& Galinski, S.F. (2012). The preoperative combination of methadone and ketamine reduces post-operative opioid usage compared with methadone alone. Acta Anaesthesiologica Scandinavica, 56(10), 1250-1256. doi:10.1111/j.1399-6576.2012.02743.x

Perez, J., Jimenez, M.J., Fita, G., Rovira, I., Catalan, M., \& Gomar, C. (2007). Epidural methadone for acute post-thoracotomy pain: An alternative to a ropivacaine plus fentanyl-based patient-controlled epidural regimen. Acute Pain 9, 193-199.

PRISMA. (2009). www.prisma-statement.org 
Sarin, A., Litonius, E. S., Naidu, R., Yost, C. S., Varma, M. G., \& Lee-lynn Chen. (2016). Successful implementation of an Enhanced Recovery After Surgery program shortens length of stay and improves postoperative pain, and bowel and bladder function after colorectal surgery. BMC Anesthesiology,16(55), 1-10. https://doi-org.ric.idm.oclc.org/10.1186/s12871-016-0223-0

Udelsmann, A., Gardini Maciel, F., Servian D.C.M., Reis, E., de Azevedo T.M., \& Melo M.D.M. (2011). Methadone and Morphine during Anesthesia Induction for Cardiac Surgery. Repercussion in Postoperative Analgesia and Prevalence of Nausea and Vomiting. Revista Brasileria de Anestesiologia, 61(6), 695-701.

Wang, H., Li, S., Liang, N., Liu, W., Liu, H., \& Liu, H. (2017). Postoperative pain experiences in Chinese adult patients after thoracotomy and video-assisted thoracic surgery. Journal of Clinical Nursing, 26(17/18), 2744-2745. Doi:10.1111/jocn.13789

Wu, C.L., Cohen, S.R., Richman, J.M, Rowlingson, A.J., Courpas, G.E., Cheung, K., ... Liu, S.S. (2005). Efficacy of Postoperative Patient-controlled and Continuous Infusion Epidural Analgesia versus Intravenous Patient Controlled Analgesia with Opioids: A Meta-analysis. Anesthesiology, 103(5), 1079-1088.

Zheng, H., Schnabel, A., Yahiaoui-Doktor, M., Meissner, W., Van Aken, H., Zahn., P., \& Pogatzki-Zahn, E. (2017). Age and preoperative pain are major confounders for sex differences in postoperative pain outcome: A prospective database analysis. Plos ONE, 12(6), 1-14. Doi:10.1371/journal.pone.01786 


\section{Appendix A}

\section{PRISMA 2009 Checklist}

\begin{tabular}{|c|c|c|c|}
\hline Section/topic & \# & Checklist item & $\begin{array}{l}\text { Reported } \\
\text { on page \# }\end{array}$ \\
\hline Risk of bias across studies & 15 & $\begin{array}{l}\text { Specify any assessment of risk of bias that may affect the cumulative evidence (e.g., publication bias, selective } \\
\text { reporting within studies). }\end{array}$ & \\
\hline Additional analyses & 16 & $\begin{array}{l}\text { Describe methods of additional analyses (e.g., sensitivity or subgroup analyses, meta-regression), if done, indicating } \\
\text { which were pre-specified. }\end{array}$ & \\
\hline \multicolumn{4}{|l|}{ RESULTS } \\
\hline Study selection & 17 & $\begin{array}{l}\text { Give numbers of studies screened, assessed for eligibility, and included in the review, with reasons for exclusions at } \\
\text { each stage, ideally with a flow diagram. }\end{array}$ & \\
\hline Study characteristics & 18 & $\begin{array}{l}\text { For each study, present characteristics for which data were extracted (e.g., study size, PICOS, follow-up period) and } \\
\text { provide the citations. }\end{array}$ & \\
\hline Risk of bias within studies & 19 & Present data on risk of bias of each study and, if available, any outcome level assessment (see item 12). & \\
\hline Results of individual studies & 20 & $\begin{array}{l}\text { For all outcomes considered (benefits or harms), present, for each study: (a) simple summary data for each } \\
\text { intervention group (b) effect estimates and confidence intervals, ideally with a forest plot. }\end{array}$ & \\
\hline Synthesis of results & 21 & Present results of each meta-analysis done, including confidence intervals and measures of consistency. & \\
\hline Risk of bias across studies & 22 & Present results of any assessment of risk of bias across studies (see Item 15). & \\
\hline Additional analysis & 23 & Give results of additional analyses, if done (e.g., sensitivity or subgroup analyses, meta-regression [see Item 16]). & \\
\hline \multicolumn{4}{|l|}{ DISCUSSION } \\
\hline Summary of evidence & 24 & $\begin{array}{l}\text { Summarize the main findings including the strength of evidence for each main outcome; consider their relevance to } \\
\text { key groups (e.g., healthcare providers, users, and policy makers). }\end{array}$ & \\
\hline Limitations & 25 & $\begin{array}{l}\text { Discuss limitations at study and outcome level (e.g., risk of bias), and at review-level (e.g., incomplete retrieval of } \\
\text { identified research, reporting bias). }\end{array}$ & \\
\hline Conclusions & 26 & Provide a general interpretation of the results in the context of other evidence, and implications for future research. & \\
\hline \multicolumn{4}{|l|}{ FUNDING } \\
\hline Funding & 27 & $\begin{array}{l}\text { Describe sources of funding for the systematic review and other support (e.g., supply of data); role of funders for the } \\
\text { systematic review. }\end{array}$ & \\
\hline
\end{tabular}

From: Moher D. Liberati A, Tetzlaff J, Attman DG, The PRISMA Group (2009). Preferred Reporting Items for Systematic Reviews and Meta-Analyses: The PRISMA Statement. PLoS Med 6(7): e1000097.
doi:10.1371/jijurnal pred1000097 For more information, visit: www.prisma-statement.org.

\section{PRISMA 2009 Checklist} Page 2 of 2

\begin{tabular}{|c|c|c|c|}
\hline Section/topic & $\#$ & Checklist Item & $\begin{array}{l}\text { Reported } \\
\text { on page \# }\end{array}$ \\
\hline \multicolumn{4}{|l|}{ TITLE } \\
\hline Title & 1 & Identify the report as a systematic review, meta-analysis, or both. & \\
\hline \multicolumn{4}{|l|}{ ABSTRACT } \\
\hline Structured summary & 2 & $\begin{array}{l}\text { Provide a structured summary including, as applicable: background; objectives; data sources; study eligibility criteria, } \\
\text { participants, and interventions; study appraisal and synthesis methods; results; limitations; conclusions and } \\
\text { implications of key findings; systematic review registration number. }\end{array}$ & \\
\hline \multicolumn{4}{|l|}{ INTRODUCTION } \\
\hline Rationale & 3 & Describe the rationale for the review in the context of what is already known. & \\
\hline Objectives & 4 & $\begin{array}{l}\text { Provide an explicit statement of questions being addressed with reference to participants, interventions, comparisons. } \\
\text { outcomes, and study design (PICOS). }\end{array}$ & \\
\hline \multicolumn{4}{|l|}{ METHODS } \\
\hline Protocol and registration & 5 & $\begin{array}{l}\text { Indicate if a review protocol exists, if and where it can be accessed (e.g., Web address), and, if available, provide } \\
\text { registration information including registration number. }\end{array}$ & \\
\hline Eligibility criteria & 6 & $\begin{array}{l}\text { Specify study characteristics (e.g., PICOS, length of follow-up) and report characteristics (e.g.. years considered, } \\
\text { language, publication status) used as criteria for eligibility. giving rationale. }\end{array}$ & \\
\hline Information sources & 7 & $\begin{array}{l}\text { Describe all information sources (e.g., databases with dates of coverage, contact with study authors to identify } \\
\text { additional studies) in the search and date last searched. }\end{array}$ & \\
\hline Search & 8 & $\begin{array}{l}\text { Present full electronic search strategy for at least one database, including any limits used, such that it could be } \\
\text { repeated. }\end{array}$ & \\
\hline Study selection & 9 & $\begin{array}{l}\text { State the process for selecting studies (i.e., screening, eligibility, included in systematic review, and, if applicable, } \\
\text { included in the meta-analysis). }\end{array}$ & \\
\hline Data collection process & 10 & $\begin{array}{l}\text { Describe method of data extraction from reports (e.g., piloted forms, independently, in duplicate) and any processes } \\
\text { for oblaining and confirming data from investigators. }\end{array}$ & \\
\hline Data items & 11 & $\begin{array}{l}\text { List and define all variables for which data were sought (e.g., PICOS, funding sources) and any assumptions and } \\
\text { simplifications made. }\end{array}$ & \\
\hline $\begin{array}{l}\text { Risk of bias in individual } \\
\text { studies }\end{array}$ & 12 & $\begin{array}{l}\text { Describe methods used for assessing risk of bias of individual studies (including specification of whether this was } \\
\text { done at the study or outcome level), and how this information is to be used in any data synthesis. }\end{array}$ & \\
\hline Summary measures & 13 & State the principal summary measures (e.g., risk ratio, difference in means). & \\
\hline Synthesis of results & 14 & $\begin{array}{l}\text { Describe the methods of handling data and combining results of studies, if done, including measures of consistency } \\
\left(e . g .1^{2} \text { for each meta-analysis. }\right.\end{array}$ & \\
\hline
\end{tabular}

$$
\text { Page } 1 \text { of } 2
$$

(Moher et al., 2009) 


\section{Appendix B}

CONSORT 2010 checklist of information to include when reporting a randomised trial*

\begin{tabular}{|c|c|c|c|}
\hline Section/Topic & $\begin{array}{c}\text { Item } \\
\text { No }\end{array}$ & Checklist item & $\begin{array}{c}\text { Reported } \\
\text { on page No }\end{array}$ \\
\hline \multicolumn{4}{|l|}{ Title and abstract } \\
\hline & 1a & Identification as a randomised trial in the title & \\
\hline & $1 \mathrm{~b}$ & Structured summary of trial design, methods, results, and conclusions (for specific guidance see CONSOAT for abstracts) & \\
\hline \multicolumn{4}{|l|}{ Introduction } \\
\hline Background and & $2 a$ & Scientific background and explanation of rationale & \\
\hline objectives & $2 b$ & Specific objectives or hypotheses & \\
\hline \multicolumn{4}{|l|}{ Methods } \\
\hline \multirow{2}{*}{ Trial design } & 3a & Description of trial design (such as parallel, factorial) including allocation ratio & \\
\hline & $3 b$ & Important changes to methods after trial commencement (such as eligibility criteria), with reasons & \\
\hline \multirow[t]{2}{*}{ Participants } & $4 a$ & Eligibility criteria for participants & \\
\hline & $4 \mathrm{~b}$ & Settings and locations where the data were collected & \\
\hline Interventions & 5 & $\begin{array}{l}\text { The interventions for each group with sufficient details to allow replication, including how and when they were } \\
\text { actually administered }\end{array}$ & \\
\hline \multirow[t]{2}{*}{ Outcomes } & $6 a$ & $\begin{array}{l}\text { Completely defined pre-specified primary and secondary outcome measures, including how and when they } \\
\text { were assessed }\end{array}$ & \\
\hline & $6 b$ & Any changes to trial outcomes after the trial commenced, with reasons & \\
\hline \multirow[t]{2}{*}{ Sample size } & $7 \mathrm{a}$ & How sample size was determined & \\
\hline & $7 \mathrm{~b}$ & When applicable, explanation of any interim analyses and stopping guidelines & \\
\hline \multicolumn{4}{|l|}{ Randomisation: } \\
\hline \multirow{2}{*}{$\begin{array}{l}\text { Sequence } \\
\text { generation }\end{array}$} & $8 a$ & Method used to generate the random allocation sequence & \\
\hline & $8 b$ & Type of randomisation; details of any restriction (such as blocking and block size) & \\
\hline $\begin{array}{l}\text { Allocation } \\
\text { concealment } \\
\text { mechanism }\end{array}$ & 9 & $\begin{array}{l}\text { Mechanism used to implement the random allocation sequence (such as sequentially numbered containers), } \\
\text { describing any steps taken to conceal the sequence until interventions were assigned }\end{array}$ & \\
\hline Implementation & 10 & $\begin{array}{l}\text { Who generated the random allocation sequence, who enrolled participants, and who assigned participants to } \\
\text { interventions }\end{array}$ & \\
\hline \multirow[t]{3}{*}{ Blinding } & $11 \mathrm{a}$ & If done, who was blinded after assignment to interventions (for example, participants, care providers, those & \\
\hline & & assessing outcomes) and how & \\
\hline & $11 \mathrm{~b}$ & If relevant, description of the similarity of interventions & \\
\hline \multirow[t]{2}{*}{ Statistical methods } & $12 a$ & Statistical methods used to compare groups for primary and secondary outcomes & \\
\hline & $12 \mathrm{~b}$ & Methods for additional analyses, such as subgroup analyses and adjusted analyses & \\
\hline \multicolumn{4}{|l|}{ Results } \\
\hline \multirow{2}{*}{$\begin{array}{l}\text { Participant flow (a } \\
\text { diagram is strongly } \\
\text { recommended) }\end{array}$} & $13 a$ & $\begin{array}{l}\text { For each group, the numbers of participants who were randomly assigned, received intended treatment, and } \\
\text { were analysed for the primary outcome }\end{array}$ & \\
\hline & $13 \mathrm{~b}$ & For each group, losses and exclusions after randomisation, together with reasons & \\
\hline \multirow{2}{*}{ Recruitment } & $14 a$ & Dates defining the periods of recruitment and follow-up & \\
\hline & $14 \mathrm{~b}$ & Why the trial ended or was stopped & \\
\hline Baseline data & 15 & A table showing baseline demographic and clinical characteristics for each group & \\
\hline Numbers analysed & 16 & $\begin{array}{l}\text { For each group, number of participants (denominator) included in each analysis and whether the analysis was } \\
\text { by original assigned groups }\end{array}$ & \\
\hline \multirow[t]{2}{*}{$\begin{array}{l}\text { Outcomes and } \\
\text { estimation }\end{array}$} & $17 \mathrm{a}$ & $\begin{array}{l}\text { For each primary and secondary outcome, results for each group, and the estimated effect size and its } \\
\text { precision (such as } 95 \% \text { confidence interval) }\end{array}$ & \\
\hline & $17 \mathrm{~b}$ & For binary outcomes, presentation of both absolute and relative effect sizes is recommended & \\
\hline Ancillary analyses & 18 & $\begin{array}{l}\text { Results of any other analyses performed, including subgroup analyses and adjusted analyses, distinguishing } \\
\text { pre-specified from exploratory }\end{array}$ & \\
\hline Harms & 19 & All important harms or unintended effects in each group (for specific guidance see CONSORT for harms) & \\
\hline \multicolumn{4}{|c|}{ ( } \\
\hline Limitations & 20 & Trial limitations, addressing sources of potential bias, imprecision, and, if relevant, multiplicity of analyses & \\
\hline Generalisability & 21 & Generalisability (external validity, applicability) of the trial findings & \\
\hline Interpretation & 22 & Interpretation consistent with results, balancing benefits and harms, and considering other relevant evidence & \\
\hline \multicolumn{4}{|l|}{ Other information } \\
\hline Registration & 23 & Registration number and name of trial registry & \\
\hline Protocol & 24 & Where the full trial protocol can be accessed, if available & \\
\hline Funding & 25 & Sources of funding and other support (such as supply of drugs), role of funders & \\
\hline
\end{tabular}

(CONSORT, 2010) 


\section{Appendix C}

\section{Data Collection Chart \#1}

\begin{tabular}{|l|l|l|l|l|l|l|l|l|l|}
\hline Author, Year & \#Pt & Ages (yr) & M/F & ASA & Procedure & Duration methadone & Control & Route \\
\hline & & & & & & & & Group \\
\hline & & & & & & & & & \\
\hline & & & & & & & & & \\
\hline
\end{tabular}




\section{Appendix D}

Data Collection Chart \#2

\begin{tabular}{|l|l|l|l|l|l|l|l|l|}
\hline $\begin{array}{l}\text { Author, } \\
\text { Year }\end{array}$ & $\begin{array}{l}\text { Agents for } \\
\text { Induction } \\
\text { of }\end{array}$ & $\begin{array}{l}\text { Agents for } \\
\text { Maintenance } \\
\text { of Anesthesia }\end{array}$ & $\begin{array}{l}\text { Admin } \\
\text { time of } \\
\text { sudy } \\
\text { drug }\end{array}$ & $\begin{array}{l}\text { Intraoperative } \\
\text { Methadone } \\
\text { dose }\end{array}$ & $\begin{array}{l}\text { Intraoperative } \\
\text { Control Dose }\end{array}$ & $\begin{array}{l}\text { Rescue } \\
\text { pain } \\
\text { dosing in } \\
\text { recovery }\end{array}$ & $\begin{array}{l}\text { Time to } 1^{\text {st }} \\
\text { rescue } \\
\text { analgesic } \\
\text { (hours) } \\
\text { methadone }\end{array}$ & $\begin{array}{l}\text { Time to 1 } \\
\text { rescue } \\
\text { analgesic } \\
\text { Control group }\end{array}$ \\
\hline & & & & & & & & \\
\hline & & & & & & & & \\
\hline
\end{tabular}




\section{Appendix E}

\section{Randomized Control Trial Chart}

\begin{tabular}{|c|c|c|c|c|c|c|c|c|c|}
\hline $\begin{array}{l}\text { Author, } \\
\text { Year }\end{array}$ & $\begin{array}{l}\text { Study } \\
\text { Type }\end{array}$ & $\begin{array}{l}\text { Consent/ } \\
\text { Funding }\end{array}$ & $\begin{array}{l}\text { Inclusion } \\
\text { Criteria }\end{array}$ & $\begin{array}{l}\text { Exclusion } \\
\text { Criteria }\end{array}$ & Randomization & Attrition & Blinding & Strengths & Limitations \\
\hline & & & & & & & & & \\
\hline & & & & & & & & & \\
\hline & & & & & & & & & \\
\hline & & & & & & & & & \\
\hline & & & & & & & & & \\
\hline
\end{tabular}




\section{Appendix F}

\section{PXRIS MA PRISMA 2009 Flow Diagram}
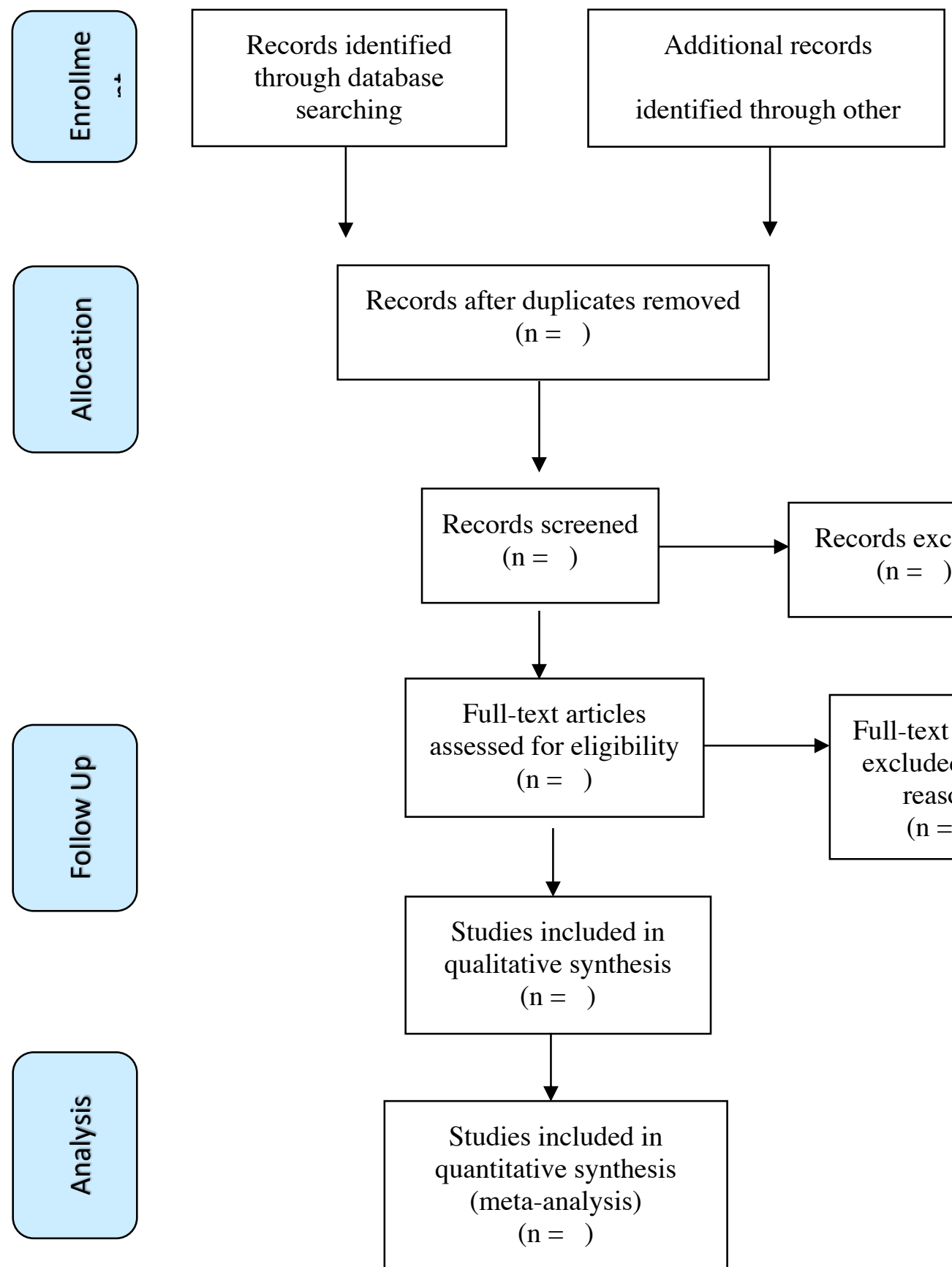

Records excluded $(\mathrm{n}=)$

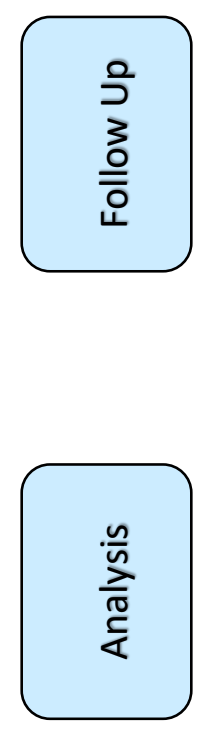

Full-text articles assessed for eligibility

antitative synthesis

$$
(\mathrm{n}=)
$$

Full-text articles excluded, with reasons $(\mathrm{n}=)$

(Moher et al., 2009) 


\section{Appendix G-1}

Data Collection Chart \#1

\begin{tabular}{|l|l|l|l|l|l|l|l|l|l|l|}
\hline & $\begin{array}{l}\text { Author, } \\
\text { Year }\end{array}$ & $\# \mathrm{Pt}$ & $\begin{array}{l}\text { Ages } \\
(\mathrm{yr})\end{array}$ & $\mathrm{M} / \mathrm{F}$ & ASA & Procedure & $\begin{array}{l}\text { Duration } \\
(\mathrm{min})\end{array}$ & $\begin{array}{l}\text { Methadone } \\
\text { Group }\end{array}$ & Control Group & Route \\
\hline $\mathrm{a}$ & $\begin{array}{l}\text { Carvalho, } \\
2011\end{array}$ & 100 & $52-73$ & $63 / 37$ & III/IV & CABG & $140-253$ & $\mathrm{n}=50$ & Morphine $\mathrm{n}=50$ & IV \\
\hline $\mathrm{b}$ & $\begin{array}{l}\text { Udelsman } \\
\mathrm{n}, \\
2011\end{array}$ & 55 & $40-72$ & $30 / 25$ & III-IV & $\begin{array}{l}\text { Cardiac } \\
\text { Surgery }\end{array}$ & $228-373$ & $\mathrm{n}=18$ & $\begin{array}{l}\text { Morphine } \mathrm{n}=19 \\
\text { saline } \mathrm{n}=18\end{array}$ & $\begin{array}{l}\text { NR } \\
\text { (inferred IV) }\end{array}$ \\
\hline $\mathrm{c}$ & $\begin{array}{l}\text { Murphy, } \\
2015\end{array}$ & 156 & $54-76$ & $115 / 4$ \\
1 & III-IV & $\begin{array}{l}\text { CABG, Valve, } \\
\text { CABG and } \\
\text { Valve, ASD }\end{array}$ & $324-371$ & $\mathrm{n}=77$ & Fentanyl $\mathrm{n}=79$ & IV \\
\hline $\mathrm{d}$ & $\begin{array}{l}\text { Matot, } \\
2004\end{array}$ & 47 & $43-72$ & $29 / 18$ & I-III & Lung Resection & $92-278$ & $\mathrm{n}=14$ & $\begin{array}{l}\text { Clonidine } \mathrm{n}=16 \\
\text { bupivacaine } \mathrm{n}=17\end{array}$ & Epidural \\
\hline e & $\begin{array}{l}\text { Perez, } \\
2007\end{array}$ & 49 & $54-61$ & NR & II-III & Lung Resection & $138-210$ & $\mathrm{n}=24$ & $\begin{array}{l}\text { ropivacaine plus } \\
\text { fentanyl } \mathrm{n}=25\end{array}$ & Bolus/ PCEA \\
\hline
\end{tabular}

$\mathrm{NR}=$ Not Reported

ASA Physical Status Classification System

ASA I: A normal, healthy patient

ASA II: A patient with mild systemic disease

ASA III: A patient with severe systemic disease

ASA IV: A patient with severe systemic disease that is a constant threat to life

ASA V: A moribund patient who is not expected to survive without the operation

ASA VI: A declared brain-dead patient whose organs are being removed for donor purposes 
Appendix G-2

Data Collection Chart \#2

\begin{tabular}{|c|c|c|c|c|c|c|c|c|c|}
\hline & Author, Year & $\begin{array}{l}\text { Agents for } \\
\text { Induction of } \\
\text { Anesthesia }\end{array}$ & $\begin{array}{l}\text { Agents for } \\
\text { Maintenance of } \\
\text { Anesthesia }\end{array}$ & $\begin{array}{l}\text { Admin } \\
\text { time of } \\
\text { study } \\
\text { drug }\end{array}$ & $\begin{array}{l}\text { Intraop } \\
\text { methadone } \\
\text { dose }\end{array}$ & $\begin{array}{l}\text { Intraoperative } \\
\text { Control Dose }\end{array}$ & $\begin{array}{l}\text { Rescue pain } \\
\text { dosing in } \\
\text { recovery }\end{array}$ & $\begin{array}{l}\text { Time to } 1^{\text {st }} \\
\text { rescue } \\
\text { analgesic } \\
\text { (hours) } \\
\text { methadone }\end{array}$ & $\begin{array}{l}\text { Time to } 1^{\text {st }} \\
\text { rescue } \\
\text { analgesic } \\
\text { (hours) } \\
\text { Control group }\end{array}$ \\
\hline $\mathrm{a}$ & $\begin{array}{l}\text { Carvalho, } \\
2011\end{array}$ & $\begin{array}{l}\text { sufentanil } \\
0.5 \mathrm{mcg} / \mathrm{kg} \text {, } \\
10 \mathrm{mcg} \\
\text { bolus PRN, } \\
\text { etomidate } \\
0.2 \mathrm{mg} / \mathrm{kg} \text {, } \\
\text { rocuronium } \\
01 . \mathrm{mg} / \mathrm{kg}\end{array}$ & $\begin{array}{l}\text { sufentanil } 0.25- \\
0.5 \mathrm{mcg} / \mathrm{kg} / \mathrm{hr} \text {, } \\
\text { sevoflurane } 0.5-1 \\
\text { MAC }\end{array}$ & $\begin{array}{l}\text { End of } \\
\text { surgery }\end{array}$ & $\begin{array}{l}\text { methadone } \\
0.1 \mathrm{mg} / \mathrm{kg}\end{array}$ & $\begin{array}{l}\text { morphine } 0.1 \\
\mathrm{mg} / \mathrm{kg}\end{array}$ & $\begin{array}{l}\text { Dipyrone } 1 \mathrm{~g} \\
\text { q } 6 \text { hours } \\
\text { continuous, } \\
\text { morphine } \\
0.03 \mathrm{mg} / \mathrm{kg} \\
\text { Limit: } 0.1 \\
\mathrm{mg} / \mathrm{kg} \text { in } 4 \mathrm{~h}\end{array}$ & $2.43 \pm 2.98$ & $4.49 \pm 4.22$ \\
\hline $\mathrm{b}$ & $\begin{array}{l}\text { Udelsmann, } \\
2011\end{array}$ & $\begin{array}{l}\text { sufentanil } \\
0.1 \mathrm{mcg} / \mathrm{kg}, \\
\text { midazolam, } \\
\text { pancuroniu } \\
\mathrm{m} 0.1 \mathrm{mg} / \mathrm{kg}\end{array}$ & $\begin{array}{l}\text { Sufentanil } 0.01 \\
\mathrm{mcg} / \mathrm{min}, \\
\text { isoflurane } 0.5 \% \\
\text { and pancuronium } \\
0.03 \mathrm{mg} / \mathrm{kg} \text { prn }\end{array}$ & $\begin{array}{l}\text { After } \\
\text { inducti } \\
\text { on }\end{array}$ & $\begin{array}{l}\text { methadone } \\
20 \mathrm{mg}\end{array}$ & $\begin{array}{l}\text { morphine } 20 \\
\mathrm{mg} \\
\text { Or } \\
\text { saline } 2 \mathrm{~mL}\end{array}$ & $\begin{array}{l}\text { morphine } \\
0.03 \mathrm{mg} / \mathrm{kg} \\
\text { prn }\end{array}$ & $\begin{array}{l}14.25 \pm \\
9.89 \text { hours }\end{array}$ & $\begin{array}{l}\text { morphine: } \\
10.43 \pm 8.75 \\
\text { saline: } 8.46 \pm \\
6.88\end{array}$ \\
\hline $\mathrm{c}$ & $\begin{array}{l}\text { Murphy, } \\
2015\end{array}$ & $\begin{array}{l}\text { midazolam } \\
4-6 \mathrm{mg} \text { PO, } \\
\text { propofol 20- } \\
\text { 100mg*, } \\
\text { rocuronium }\end{array}$ & $\begin{array}{l}\text { sevoflurane } 0.4- \\
3 \% * * \\
\text { rocuronium, } \\
\text { midazolam } 5 \mathrm{mg} \\
\text { during }\end{array}$ & $\begin{array}{l}1 / 2 \text { at } \\
\text { inducti } \\
\text { on } \\
1 / 2 \\
\text { infused }\end{array}$ & $\begin{array}{l}\text { methadone } \\
0.15 \mathrm{mg} / \mathrm{kg}\end{array}$ & $\begin{array}{l}\text { fentanyl } 6 \\
\mathrm{mcg} / \mathrm{kg}\end{array}$ & $\begin{array}{l}\text { morphine } 2 \\
\text { mg until pain } \\
<3 \\
\text { hydrocodone } \\
\text { / APAP } 1 \text { tab }\end{array}$ & $\begin{array}{l}6.5(3.25- \\
9.25)\end{array}$ & $\begin{array}{l}3.75(1.5- \\
5.75)\end{array}$ \\
\hline
\end{tabular}




\begin{tabular}{|c|c|c|c|c|c|c|c|c|c|}
\hline & & $\begin{array}{l}0.6- \\
08 . \mathrm{mg} / \mathrm{kg}\end{array}$ & $\begin{array}{l}\text { rewarming, } \\
\text { propofol 10- } \\
50 \mathrm{mcg} / \mathrm{kg} / \mathrm{min} @ \\
\text { closure }\end{array}$ & $\begin{array}{l}\text { over } \\
\text { next } 2 \\
\text { hrs }\end{array}$ & & & $\begin{array}{l}\text { mild pain, } 2 \\
\text { tabs for } \\
\text { moderate- } \\
\text { severe pain }\end{array}$ & & \\
\hline d & Matot, 2004 & $\begin{array}{l}\text { diazepam } 10 \\
\mathrm{mg} \mathrm{PO}, \\
\mathrm{propofol} 2 \\
\mathrm{mg} / \mathrm{kg}, \\
\text { fentanyl } 2 \\
\mathrm{mcg} / \mathrm{kg}, \\
\text { vecuronium } \\
0.1 \mathrm{mg} / \mathrm{kg}\end{array}$ & $\begin{array}{l}\text { isoflurane and a } \\
50 \% \text { oxygen with } \\
\text { nitrous oxide } \\
\text { mixture with } \\
\text { fentanyl } 1.5 \\
\mathrm{mcg} / \mathrm{kg} \text { boluses } \\
\text { prn pain }\end{array}$ & $\begin{array}{l}\text { Skin } \\
\text { closure } \\
\text { at end } \\
\text { of case }\end{array}$ & $\begin{array}{l}\text { methadone } \\
6 \mathrm{mg} \\
\text { bolus, } \\
\text { infusion of } \\
0.5 \mathrm{mg} / \mathrm{hr}\end{array}$ & $\begin{array}{l}\text { clonidine: } 8 \\
\mathrm{mcg} / \mathrm{kg} \\
\text { bolus with } \\
\text { infusion } 1 \\
\mathrm{mcg} / \mathrm{kg} / \mathrm{hr} \\
\text { bupivacaine: } \\
0.25 \% 10 \\
\mathrm{~mL} \text { bolus, } \\
\text { then } 0.125 \% \\
\text { infusion of } \\
10 \mathrm{ml} / \mathrm{hr}\end{array}$ & $\begin{array}{l}\text { diclofenac } \\
75 \mathrm{mg} \text { IM }\end{array}$ & NR & NR \\
\hline e & Perez, 2007 & $\begin{array}{l}\text { midazolam, } \\
\text { propofol, } \\
\text { fentanyl, } \\
\text { rocuronium } \\
\text { (doses NR) }\end{array}$ & $\begin{array}{l}\text { propofol, fentanyl } \\
\text { and rocuronium } \\
\text { (doses NR) }\end{array}$ & $\begin{array}{l}\text { Closure } \\
\text { of chest } \\
\text { cavity }\end{array}$ & $\begin{array}{l}\text { methadone } \\
4-6 \mathrm{mg} \\
\text { epidural } \\
0.1 \% \text { q } 8 \\
\text { hour bolus }\end{array}$ & $\begin{array}{l}\text { ropivacaine } \\
0.16 \% \text { plus } \\
\text { fentanyl } 3.5 \\
\mathrm{mcg} \mathrm{CI} \mathrm{6-} \\
10 \mathrm{ml} / \mathrm{hr} \text {. }\end{array}$ & $\begin{array}{l}\text { Scheduled } \\
\text { ketorolac } 30 \\
\text { mg q } 8 \mathrm{hr} . \\
\text { Rescue: } \\
\text { propacetamo } \\
12 \mathrm{mg} \text { QID }\end{array}$ & NR & NR \\
\hline
\end{tabular}

ABW: Adjusted Body Weight

*- titrated to loss of consciousness

**- titrated to BIS monitoring of 40-60 and MAPs within $20 \%$ of baseline

$\mathrm{CI}=$ Continuous Infusion

$\mathrm{NR}=$ Not Reported 
Randomized Control Trial Appraisal Chart

\section{Appendix G-3}

\begin{tabular}{|c|c|c|c|c|c|c|c|c|c|c|}
\hline & $\begin{array}{l}\text { Author, } \\
\text { Year }\end{array}$ & $\begin{array}{l}\text { Study } \\
\text { Type }\end{array}$ & $\begin{array}{l}\text { Consent/ } \\
\text { Funding }\end{array}$ & $\begin{array}{l}\text { Inclusion } \\
\text { Criteria }\end{array}$ & $\begin{array}{l}\text { Exclusion } \\
\text { Criteria }\end{array}$ & Randomization & Attrition & Blinding & Strengths & Limitations \\
\hline $\mathrm{a}$ & $\begin{array}{l}\text { Carvalho, } \\
2011\end{array}$ & $\begin{array}{l}\text { RCT, } \\
\text { double } \\
\text { blind, } \\
\text { parallel } \\
\text { clinical } \\
\text { trial }\end{array}$ & $\begin{array}{l}\text { Ethics } \\
\text { Committee } \\
\text { approval, } \\
\text { Written } \\
\text { informed } \\
\text { consent }\end{array}$ & $\begin{array}{l}\text { M/F, over } \\
18 \text { years, } \\
\text { ASA III or } \\
\text { IV, CABG } \\
\text { without } \\
\text { Cardiopul } \\
\text { monary } \\
\text { bypass } \\
\text { (CPB) }\end{array}$ & $\begin{array}{l}\text { Illicit drug } \\
\text { use, } \\
\text { allergies to } \\
\text { medications } \\
\text { used, those } \\
\text { remained } \\
\text { intubated } \\
>12 \text { hours } \\
\text { postop }\end{array}$ & $\begin{array}{l}\text { Block } \\
\text { randomized } \\
\text { into two } \\
\text { treatment } \\
\text { groups and } \\
\text { passed to head } \\
\text { of department } \\
\text { to determine } \\
\text { treatment } \\
\text { group }\end{array}$ & $\begin{array}{l}\mathrm{n}=4: \\
1 \text { death, one } \\
\text { reintubation } \\
\text { and } 2 \\
\text { intubated }> \\
12 \text { hours }\end{array}$ & $\begin{array}{l}\text { Patients, } \\
\text { researcher } \\
\mathrm{s} \text { and } \\
\text { research } \\
\text { assistants } \\
\text { blinded }\end{array}$ & $\begin{array}{l}\text { Generaliz- } \\
\text { able, no } \\
\text { proportional } \\
\text { difference } \\
\text { between } \\
\text { gender } \\
\text { groups, } \\
\text { methadone } \\
\text { efficacy 22\% } \\
\text { higher }\end{array}$ & $\begin{array}{l}\text { Only looked } \\
\text { at first } 36 \\
\text { postop hours, } \\
\text { pain is } \\
\text { extremely } \\
\text { subjective, no } \\
\text { standardized } \\
\text { measure for } \\
\text { assessing } \\
\text { level of } \\
\text { sedation }\end{array}$ \\
\hline b & $\begin{array}{l}\text { Udelsmann, } \\
2011\end{array}$ & $\begin{array}{l}\text { RCT, } \\
\text { double } \\
\text { blind } \\
\text { study }\end{array}$ & $\begin{array}{l}\text { Ethics } \\
\text { Committee } \\
\text { approval, } \\
\text { informed } \\
\text { consent }\end{array}$ & $\begin{array}{l}\text { Male, } \\
\text { female, 14- } \\
80 \text { years } \\
\text { old, ASA } \\
\text { III or IV, } \\
\text { cardiac } \\
\text { surgery } \\
\text { with CPB }\end{array}$ & $\begin{array}{l}\text { Illicit drugs } \\
\text { or } \\
\text { antidepressa } \\
\text { nts, } \\
\text { psychiatric } \\
\text { disease, } \\
\text { allergies to } \\
\text { drugs used, } \\
\text { intubation } \\
>24 \text { hours } \\
\text { postoperativ } \\
\text { ely }\end{array}$ & NR & NR & $\begin{array}{l}\text { Anesthesi } \\
\text { a MD and } \\
\text { patient }\end{array}$ & $\begin{array}{l}\text { Generaliz- } \\
\text { able, no } \\
\text { proportional } \\
\text { difference } \\
\text { between } \\
\text { gender } \\
\text { groups, } \\
\text { Evaluated } \\
\text { number of } \\
\text { patients } \\
\text { requiring } \\
\text { analgesics } \\
\text { and NRS } \\
\text { scores }\end{array}$ & $\begin{array}{l}\text { Small sample } \\
\text { size, Poor } \\
\text { description of } \\
\text { methods, } \\
\text { randomizatio } \\
n \text { and } \\
\text { attrition, pain } \\
\text { scores } \\
\text { recorded at } \\
24 \text { hours } \\
\text { postoperative, } \\
\text { no report on } \\
\text { levels of pain }\end{array}$ \\
\hline
\end{tabular}




\begin{tabular}{|c|c|c|c|c|c|c|c|c|c|c|}
\hline & $\begin{array}{l}\text { Author, } \\
\text { Year }\end{array}$ & $\begin{array}{l}\text { Study } \\
\text { Type }\end{array}$ & $\begin{array}{l}\text { Consent/ } \\
\text { Funding }\end{array}$ & $\begin{array}{l}\text { Inclusion } \\
\text { Criteria }\end{array}$ & $\begin{array}{l}\text { Exclusion } \\
\text { Criteria }\end{array}$ & Randomization & Attrition & Blinding & Strengths & Limitations \\
\hline & & & & & & & & & & $\begin{array}{l}\text { throughout } 24 \\
\text { hours- } \\
\text { published as a } \\
\text { mean of pain } \\
\text { score } \\
\text { throughout } 24 \\
\text { hour period }\end{array}$ \\
\hline c & $\begin{array}{l}\text { Murphy, } \\
2015\end{array}$ & $\begin{array}{l}\text { RCT, } \\
\text { double } \\
\text { blind }\end{array}$ & $\begin{array}{l}\text { IRB } \\
\text { approval, } \\
\text { written } \\
\text { informed } \\
\text { consent }\end{array}$ & $\begin{array}{l}\text { Elective } \\
\text { cardiac } \\
\text { surgery } \\
\text { (CABG, } \\
\text { valve, } \\
\text { CABG and } \\
\text { valve, and } \\
\text { atrial } \\
\text { septal } \\
\text { defect } \\
\text { repair) } \\
\text { with CPB } \\
\text { and } \\
\text { extubation } \\
<12 \text { hours } \\
\text { from } \\
\text { surgery }\end{array}$ & $\begin{array}{l}\text { Preop renal } \\
\text { failure } \\
\text { requiring } \\
\text { dialysis, } \\
\text { serum } \\
\text { creatinine } \\
>2.0 \text {, } \\
\text { significant } \\
\text { hepatic } \\
\text { dysfunction, } \\
\mathrm{EF}<30 \% \text {, } \\
\text { home O2 } \\
\text { therapy, } \\
\text { emergency } \\
\text { surgery, } \\
\text { preoperative } \\
\text { requirement } \\
\text { of } \\
\text { inotropes/I } \\
\text { ABP, } \\
\text { allergy to } \\
\text { drugs in }\end{array}$ & $\begin{array}{l}\text { Computer } \\
\text { generated } \\
\text { randomization } \\
\text { code }\end{array}$ & $\begin{array}{l}\mathrm{n}=8: \\
3 \text { protocol } \\
\text { violations, } 1 \\
\text { canceled } \\
\text { surgery, } 1 \\
\text { study drug } \\
\text { unavailable } \\
\text { at time of } \\
\text { surgery, } 2 \\
\text { severe HTN } \\
\text { prior to start } \\
\text { of study } \\
\text { drug, } 1 \\
\text { death }\end{array}$ & $\begin{array}{l}\text { All } \\
\text { research } \\
\text { team } \\
\text { members } \\
\text { and } \\
\text { nurses }\end{array}$ & 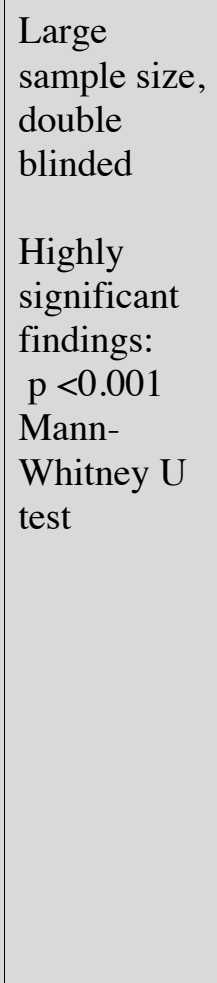 & $\begin{array}{l}\text { Optimal } \\
\text { intraoperative } \\
\text { dose of } \\
\text { methadone } \\
\text { not } \\
\text { determined, } \\
\text { only followed } \\
\text { for } 72 \text { hours, } \\
\text { high risk } \\
\text { cardiac } \\
\text { patients were } \\
\text { excluded, } \\
\text { chronic pain } \\
\text { not reported } \\
\text { postop }\end{array}$ \\
\hline
\end{tabular}




\begin{tabular}{|c|c|c|c|c|c|c|c|c|c|c|}
\hline & $\begin{array}{l}\text { Author, } \\
\text { Year }\end{array}$ & $\begin{array}{l}\text { Study } \\
\text { Type }\end{array}$ & $\begin{array}{l}\text { Consent/ } \\
\text { Funding }\end{array}$ & $\begin{array}{l}\text { Inclusion } \\
\text { Criteria }\end{array}$ & $\begin{array}{l}\text { Exclusion } \\
\text { Criteria }\end{array}$ & Randomization & Attrition & Blinding & Strengths & Limitations \\
\hline & & & & & $\begin{array}{l}\text { study, } \\
\text { opioid } \\
\text { abuse or } \\
\text { preoperative } \\
\text { opioid use }\end{array}$ & & & & & \\
\hline d & Matot, 2004 & $\begin{array}{l}\text { RCT, } \\
\text { double } \\
\text { blind } \\
\text { prospec } \\
\text { tive } \\
\text { study }\end{array}$ & $\begin{array}{l}\text { IRB } \\
\text { approval, } \\
\text { Written } \\
\text { and } \\
\text { informed } \\
\text { consent }\end{array}$ & $\begin{array}{l}>18 \text { years } \\
\text { old, } \\
\text { elective } \\
\text { thoracotom } \\
\text { y for left } \\
\text { lobectomy }\end{array}$ & $\begin{array}{l}\text { Contraindic } \\
\text { ation to } \\
\text { epidural, } \\
\text { chronic } \\
\text { NSAID use, } \\
\text { allergy to } \\
\text { drugs, lack } \\
\text { of co- } \\
\text { operation, } \\
\text { renal or } \\
\text { hepatic } \\
\text { dysfunction, } \\
\text { use of } \\
\text { clonidine, } \\
\text { chronic } \\
\text { opioids or } \\
\text { psychotropi } \\
\text { c drugs, } \\
\text { history of } \\
\text { chronic } \\
\text { pain, resting } \\
\text { HR <50 or } \\
\text { left bundle } \\
\text { branch }\end{array}$ & $\begin{array}{l}\text { During skin } \\
\text { closure, } \\
\text { randomly } \\
\text { allocated to a } \\
\text { table of } \\
\text { random } \\
\text { numbers for } 1 \\
\text { of } 3 \\
\text { postoperative } \\
\text { epidural } \\
\text { analgesia }\end{array}$ & $\begin{array}{l}\mathrm{n}=7 \\
\text { excluded } \\
\text { for } \\
\text { intraoperati } \\
\text { ve reasons }\end{array}$ & $\begin{array}{l}\text { Double } \\
\text { blinded }\end{array}$ & $\begin{array}{l}\text { Evaluated } 3 \\
\text { different } \\
\text { classes of } \\
\text { drugs: } \\
\text { opioid, local } \\
\text { anesthetic } \\
\text { and alpha } \\
\text { agonist }\end{array}$ & $\begin{array}{l}\text { Option for } \\
\text { best analgesic } \\
\text { based } \\
\text { primarily on } \\
\text { PFTs, small } \\
\text { sample size, } \\
\text { limited } \\
\text { information } \\
\text { regarding } \\
\text { pain } \\
\text { management, } \\
\text { evaluated } \\
\text { pain for } 72 \\
\text { hours, pain } \\
\text { scores not } \\
\text { reported, not } \\
\text { described } \\
\text { how the study } \\
\text { was blinded, } \\
\text { unequal } \\
\text { intervention } \\
\text { groups }\end{array}$ \\
\hline
\end{tabular}




\begin{tabular}{|c|c|c|c|c|c|c|c|c|c|c|}
\hline & $\begin{array}{l}\text { Author, } \\
\text { Year }\end{array}$ & $\begin{array}{l}\text { Study } \\
\text { Type }\end{array}$ & $\begin{array}{l}\text { Consent/ } \\
\text { Funding }\end{array}$ & $\begin{array}{l}\text { Inclusion } \\
\text { Criteria }\end{array}$ & \begin{tabular}{|l} 
Exclusion \\
Criteria
\end{tabular} & Randomization & Attrition & Blinding & Strengths & Limitations \\
\hline & & & & & $\begin{array}{l}\text { block or } \\
\text { need for } \\
\text { more } \\
\text { extensive } \\
\text { surgery }\end{array}$ & & & & & \\
\hline e & Perez, 2007 & $\begin{array}{l}\text { Prospec } \\
\text { tive, } \\
\text { RCT, } \\
\text { open } \\
\text { label } \\
\text { clinical } \\
\text { trial }\end{array}$ & $\begin{array}{l}\text { Ethics } \\
\text { committee } \\
\text { approval } \\
\text { Informed, } \\
\text { signed } \\
\text { consent }\end{array}$ & $\begin{array}{l}\text { ASA II or } \\
\text { III, } \\
\text { scheduled } \\
\text { elective } \\
\text { thoracotom } \\
\text { y for lung } \\
\text { resection } \\
\text { surgery, } \\
\text { No } \\
\text { contraindic } \\
\text { ations to } \\
\text { epidural, } \\
\text { preoperativ } \\
\text { e FEV1 } \\
>1000 \mathrm{~mL}\end{array}$ & $\begin{array}{l}\text { Contraindic } \\
\text { ations to } \\
\text { epidural } \\
\text { including: } \\
\text { coagulation } \\
\text { impairment } \\
\text { or patient } \\
\text { refusal, } \\
\text { preoperative } \\
\text { FEV1 } \\
<1000 \mathrm{~mL}\end{array}$ & $\begin{array}{l}\text { Computer } \\
\text { generated } \\
\text { program into } 2 \\
\text { groups }\end{array}$ & 0 & $\begin{array}{l}\text { Non- } \\
\text { blinded } \\
\text { open } \\
\text { study }\end{array}$ & $\begin{array}{l}\text { High degree } \\
\text { of treatment } \\
\text { satisfaction, } \\
48 \text { hour } \\
\text { study with a } \\
4 \text { month } \\
\text { telephone } \\
\text { follow up, } \\
\text { patient } \\
\text { demographic } \\
\text { s } \\
\text { proportional }\end{array}$ & $\begin{array}{l}\text { Non-blinded, } \\
\text { small sample } \\
\text { size, time to } \\
\text { first analgesic } \\
\text { dose not well } \\
\text { described }\end{array}$ \\
\hline
\end{tabular}




\section{Appendix H-1}

Carvalho, A.C., Goulart Sebold, F.J., Garcia Calegari, P.M., Heleno de Oliveria, B., \& Schuelter-Trevisol, F. (2018). Comparison of postoperative analgesia with methadone versus morphine in cardiac surgery. Revista Brasileira de Anestesiolgia, 68(2), 122-127.

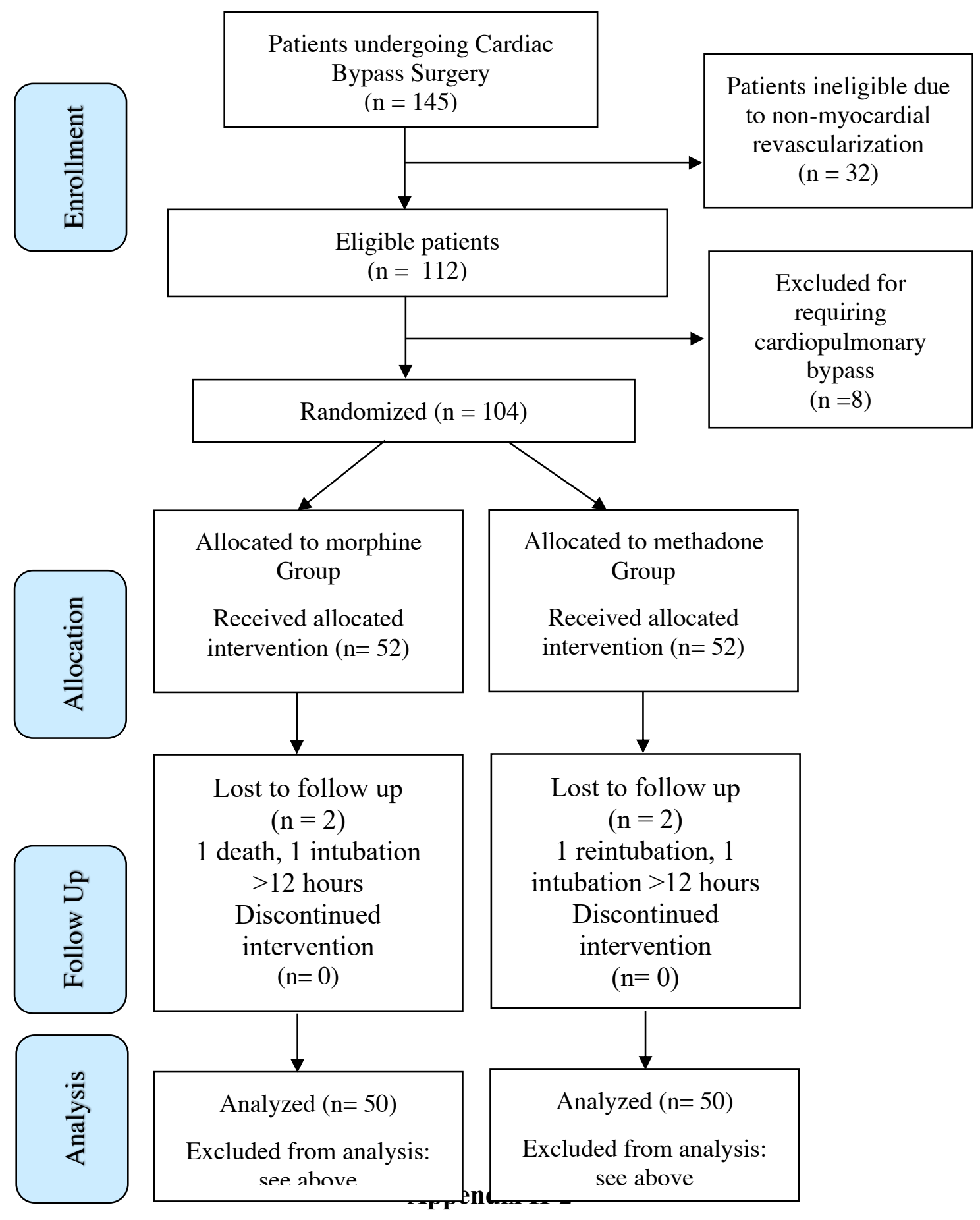


Udelsmann, A., Gardini Maciel, F., Servian D.C.M., Reis, E., de Azevedo T.M., Melo M.D.M. (2011). Methadone and Moprhine during Anesthesia Induction for Cardiac Surgery. Repercussion in Postoperative Analgesia and Prevalence of Nausea and Vomiting. Revista Brasileria de Anestesiologia, 61(6), 695-701.

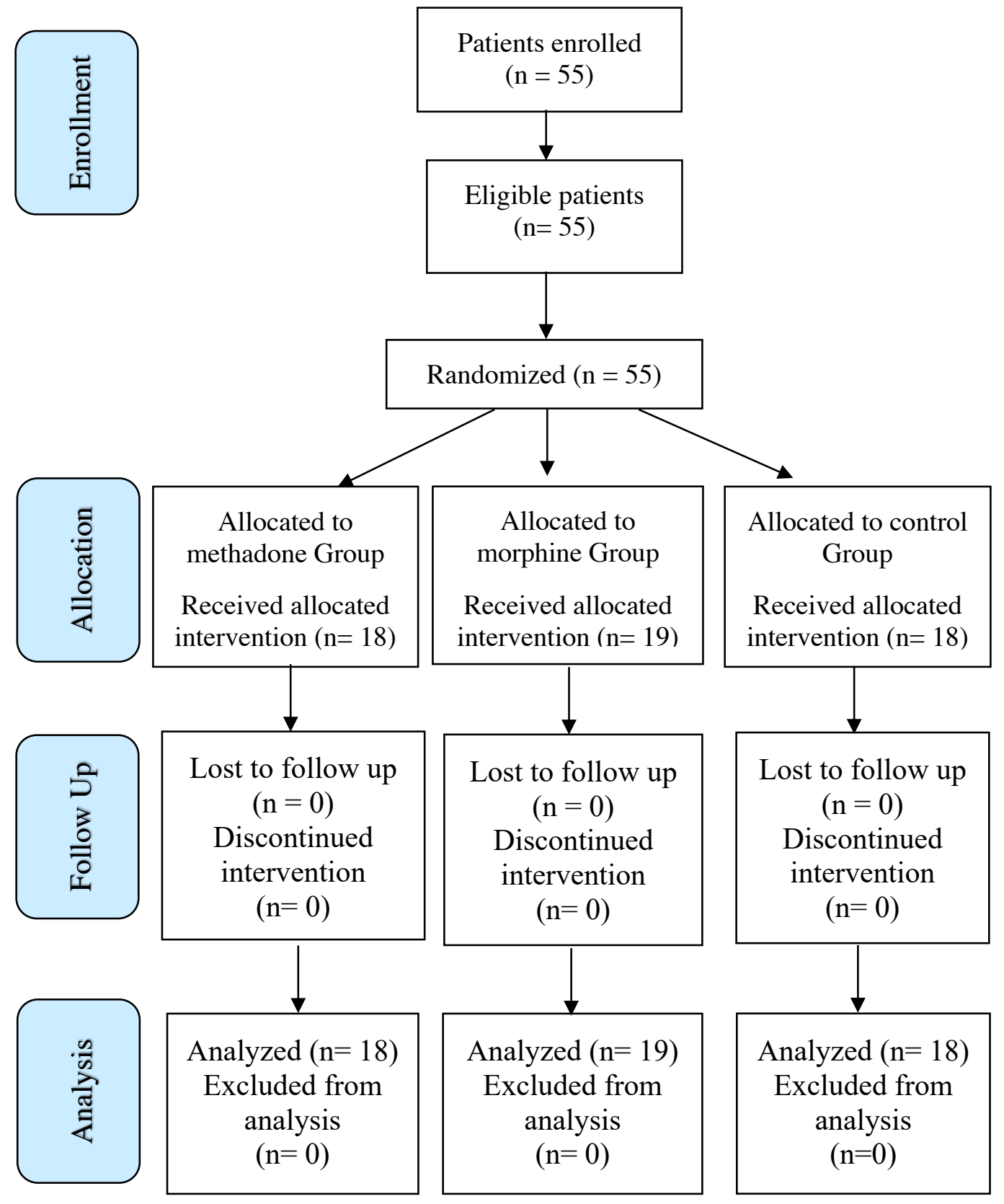


Murphy, G.S., Szokol, J.W., Avram, M.J., Greengerg, S.B., Marymont, J.H., Shear, T., Parikh, K.N., Patel, S.S., Gupta, D.K. (2015). Intraoperative Methadone for the Prevention of Postoperative Pain: A Randomized, Double-blinded Clinical Trial in Cardiac Surgical Patients. Anesthesiology, 122(5), 1112-1122.

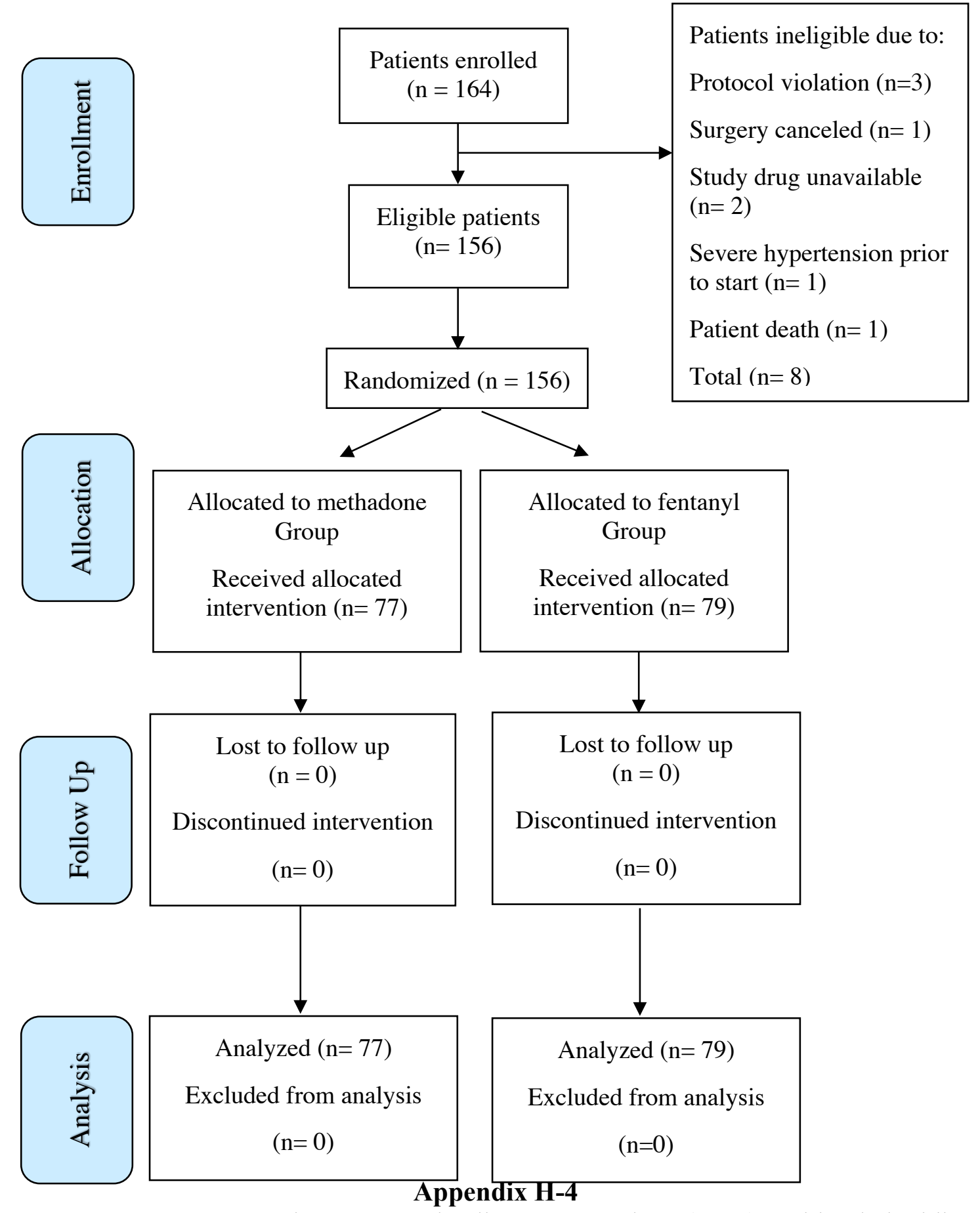

Matot, I., Drenger, B., Weissman, C., Shauli, A., \& Gozal, Y. (2004). Epidural clonidine, 
bupivacaine and methadone as the sole analgesic agent after thoracotomy for lung resection. Anaesthesia, 59, 861-866.

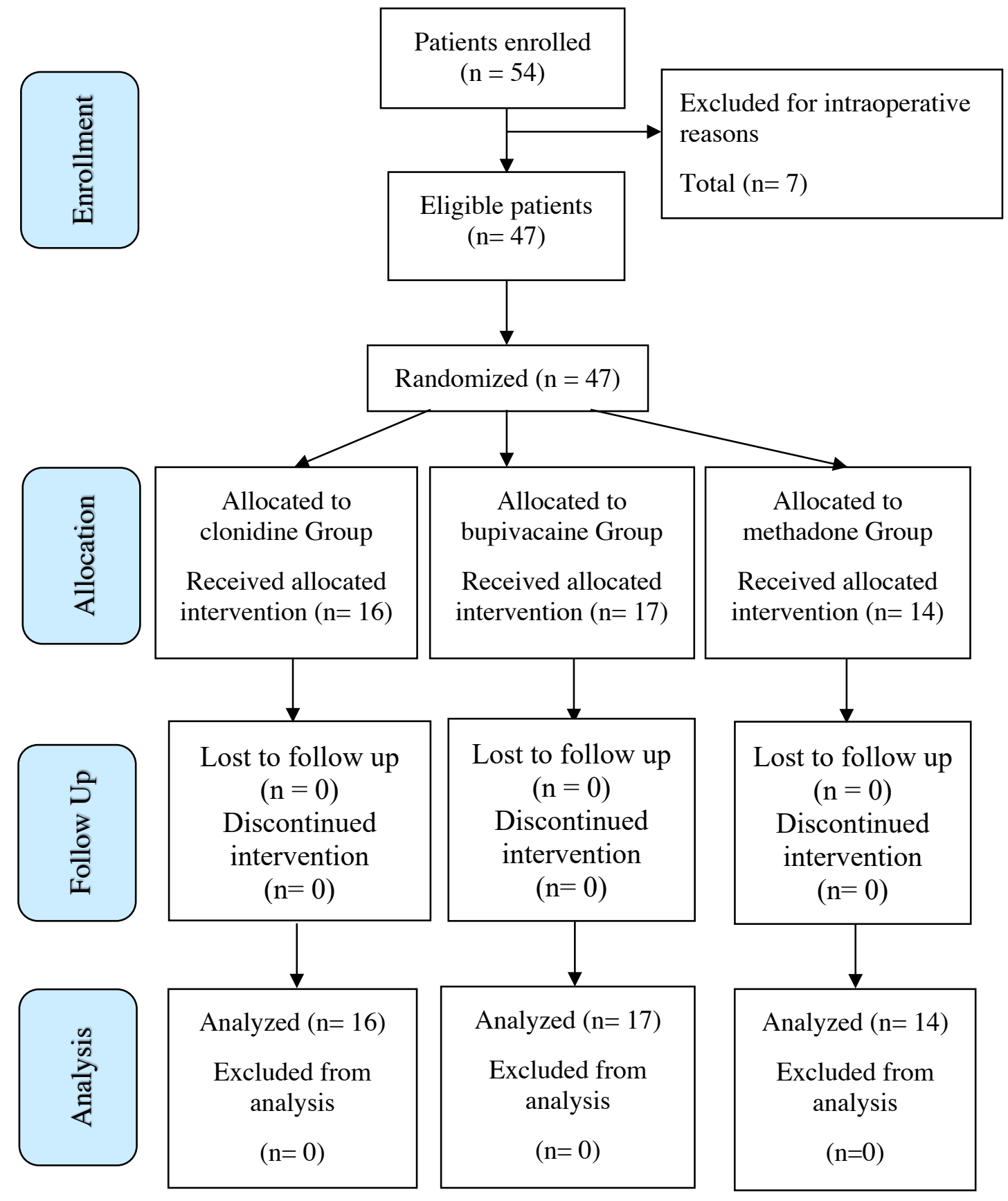




\section{Appendix H-5}

Perez, J., Jimenez, M.J., Fita, G., Rovira, I., Catalan, M., Gomar, C. (2007). Epidural methadone for acute post-thoracotomy pain: An alternative to a ropivacaine plus fentanyl-based patient-controlled epidural regimen. Acute Pain 9,193-199.

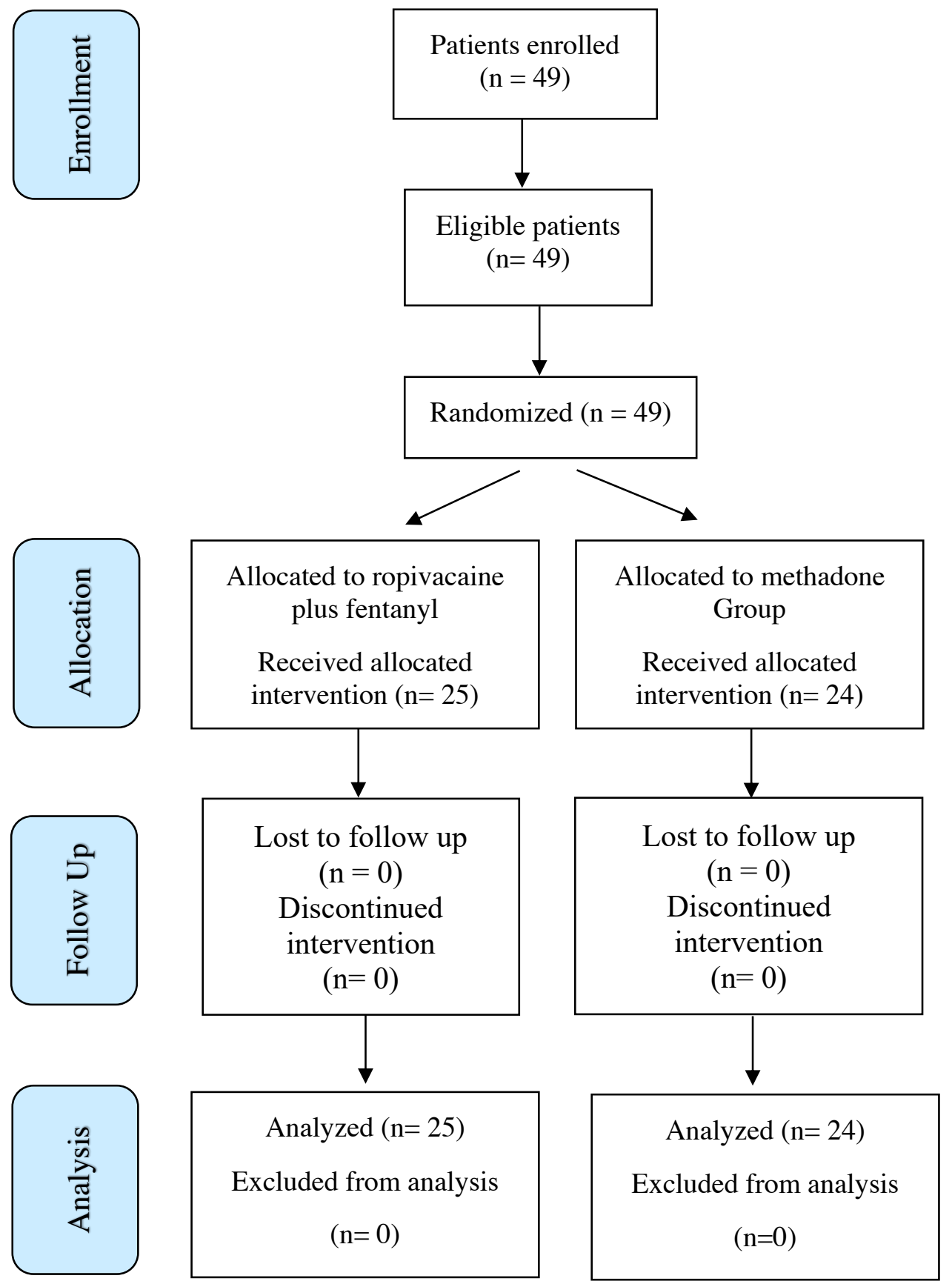




\section{Appendix I}

Cross Study Analysis

\begin{tabular}{|c|c|c|c|c|c|c|c|c|}
\hline & $\begin{array}{l}\text { Author, } \\
\text { Year }\end{array}$ & $\begin{array}{l}\text { Surgery } \\
\text { Time } \\
\text { (hours) }\end{array}$ & $\begin{array}{l}\text { Time to } \\
\text { Extubation } \\
\text { (hours) }\end{array}$ & $\begin{array}{l}\text { Time to } 1^{\text {st }} \\
\text { rescue } \\
\text { analgesic } \\
\text { (hours) }\end{array}$ & $\begin{array}{l}\text { NRS in first } \\
24 \text { hours }\end{array}$ & $\begin{array}{l}\text { NRS } \\
\text { Extended } \\
\text { period }\end{array}$ & $\begin{array}{l}\text { Reported } \\
\text { rescue } \\
\text { drug use }\end{array}$ & Adverse Events \\
\hline $\mathrm{a}$ & $\begin{array}{l}\text { Carvalho, } \\
2011\end{array}$ & $\begin{array}{l}\text { methadone: } \\
2.48-4.23 \\
\text { morphine: } \\
2.34-3.9\end{array}$ & $\begin{array}{l}\text { methadone: } \\
0.57-7.69 \\
\text { morphine: } \\
1.23-6.33\end{array}$ & $\begin{array}{l}\text { methadone: } \\
2.43 \pm 2.98 \\
\text { morphine: } \\
4.49 \pm 4.22\end{array}$ & $\begin{array}{l}\text { methadone: } \\
1.9 \pm 2.2 \\
\text { morphine: } \\
2.9 \pm 2.6\end{array}$ & $\begin{array}{l}\text { At } 36 \\
\text { hours: } \\
\text { methadone: } \\
0.5 \pm 1.2 \\
\text { morphine: } \\
0.5 \pm 1.1\end{array}$ & $\begin{array}{l}\text { morphine } \\
\text { use: } \\
\text { methadone } \\
: 29 \% \\
\text { morphine: } \\
43 \%\end{array}$ & $\begin{array}{l}\text { Adverse } \\
\text { Effects: } \\
\text { methadone: } 16 \% \\
\text { morphine: } 19 \% \\
\text { Nausea } \\
\text { methadone: } 15 \% \\
\text { morphine: } 19 \% \\
\text { Vomiting: } \\
\text { methadone: } 5 \% \\
\text { morphine: } 3 \% \\
\text { Respiratory } \\
\text { Failure: } \\
\text { methadone: } 2 \% \\
\text { morphine: } 1 \%\end{array}$ \\
\hline $\mathrm{b}$ & $\begin{array}{l}\text { Udelsmann, } \\
2011\end{array}$ & $\begin{array}{l}\text { methadone: } \\
4.75 \pm 0.84 \\
\text { morphine: } \\
4.77 \pm 0.96\end{array}$ & $\begin{array}{l}\text { methadone: } \\
7.18 \pm 5.07 \\
\text { morphine: } \\
5.98 \pm 2.99\end{array}$ & $\begin{array}{l}\text { methadone: } \\
14.25 \pm \\
9.89\end{array}$ & $\begin{array}{l}\text { methadone: } \\
0.5 \pm 0.71 \\
\text { morphine: } \\
1.84 \pm 1.38\end{array}$ & $\begin{array}{l}\text { Not } \\
\text { Applicable }\end{array}$ & $\begin{array}{l}\text { methadone } \\
: 10 / 18 \\
\text { needed } \\
\text { rescue } \\
\text { morphine }\end{array}$ & $\begin{array}{l}\text { PONV* } \\
\text { methadone: } 1 / 18 \\
\text { morphine: } 6 / 19\end{array}$ \\
\hline
\end{tabular}




\begin{tabular}{|c|c|c|c|c|c|c|c|c|}
\hline & $\begin{array}{l}\text { Author, } \\
\text { Year }\end{array}$ & $\begin{array}{l}\text { Surgery } \\
\text { Time } \\
\text { (hours) }\end{array}$ & $\begin{array}{l}\text { Time to } \\
\text { Extubation } \\
\text { (hours) }\end{array}$ & $\begin{array}{l}\text { Time to } 1^{\text {st }} \\
\text { rescue } \\
\text { analgesic } \\
\text { (hours) }\end{array}$ & $\begin{array}{l}\text { NRS in first } \\
24 \text { hours }\end{array}$ & $\begin{array}{l}\text { NRS } \\
\text { Extended } \\
\text { period }\end{array}$ & $\begin{array}{l}\text { Reported } \\
\text { rescue } \\
\text { drug use }\end{array}$ & Adverse Events \\
\hline & & $\begin{array}{l}\text { saline: } 5.05 \\
\pm 1.17\end{array}$ & $\begin{array}{l}\text { saline: } 5.69 \pm \\
2.41\end{array}$ & $\begin{array}{l}\text { morphine: } \\
10.43 \pm \\
8.75 \\
\text { saline: } 8.46 \\
\pm 6.88\end{array}$ & $\begin{array}{l}\text { saline: } 2.39 \\
\pm 2.18\end{array}$ & & $\begin{array}{l}\text { morphine: } \\
14 / 19 \\
\text { needed } \\
\text { rescue } \\
\text { morphine } \\
\text { saline: } \\
17 / 18 \\
\text { needed } \\
\text { rescue } \\
\text { morphine }\end{array}$ & saline: $9 / 18$ \\
\hline c & $\begin{array}{l}\text { Murphy, } \\
2015\end{array}$ & $\begin{array}{l}\text { methadone: } \\
5.40-7.10 \\
\text { fentanyl: } \\
5.52-7.12\end{array}$ & $\begin{array}{l}\text { methadone: } \\
5.0-9.5 \\
\text { fentanyl: } \\
4.75-10.5\end{array}$ & $\begin{array}{l}\text { methadone: } \\
6.5(3.25- \\
9.25) \\
\text { fentanyl: } \\
3.75(1.5- \\
5.75)\end{array}$ & $\begin{array}{l}\text { NRS at rest: } \\
\text { methadone: } \\
2(1-4) \\
\text { fentanyl: } 4 \\
(2-7) \\
\text { NRS with } \\
\text { coughing: } \\
\text { methadone: } \\
4(3-5) \\
\text { fentanyl: } 7 \\
(5-9)\end{array}$ & $\begin{array}{l}\text { NRS @ } 72 \\
\text { hours at } \\
\text { rest: } \\
\text { methadone: } \\
2(0-3) \\
\text { fentanyl: } 3 \\
(0-5) \\
\\
\text { NRS @ } 72 \\
\text { hours with } \\
\text { coughing: } \\
\text { methadone: } \\
4(2-5)\end{array}$ & $\begin{array}{l}\text { morphine } \\
\text { use in first } \\
24 \text { hours } \\
(\mathrm{mg}) \text { : } \\
\text { methadone } \\
: \quad 6 \mathrm{mg} \\
(4-12) \\
\text { fentanyl: } \\
10 \mathrm{mg}(6- \\
22)\end{array}$ & $\begin{array}{l}\text { Nausea: } \\
\text { methadone: } 50 \% \\
\text { fentanyl: } 56 \% \\
\text { Vomiting: } \\
\text { methadone: } 24 \% \\
\text { fentanyl: } 19 \% \\
\text { Pruritis: } \\
\text { methadone: } 22 \% \\
\text { fentanyl: } 12 \% \\
\text { Hypoventilatio } \\
\text { n: }\end{array}$ \\
\hline
\end{tabular}




\begin{tabular}{|c|c|c|c|c|c|c|c|c|}
\hline & $\begin{array}{l}\text { Author, } \\
\text { Year }\end{array}$ & $\begin{array}{l}\text { Surgery } \\
\text { Time } \\
\text { (hours) }\end{array}$ & $\begin{array}{l}\text { Time to } \\
\text { Extubation } \\
\text { (hours) }\end{array}$ & $\begin{array}{l}\text { Time to } 1^{\text {st }} \\
\text { rescue } \\
\text { analgesic } \\
\text { (hours) }\end{array}$ & $\begin{array}{l}\text { NRS in first } \\
24 \text { hours }\end{array}$ & $\begin{array}{l}\text { NRS } \\
\text { Extended } \\
\text { period }\end{array}$ & $\begin{array}{l}\text { Reported } \\
\text { rescue } \\
\text { drug use }\end{array}$ & Adverse Events \\
\hline & & & & & & $\begin{array}{l}\text { fentanyl: } 5 \\
(3-7)\end{array}$ & & $\begin{array}{l}\text { methadone: } 4 \% \\
\text { fentanyl: } 4 \% \\
\text { Hypoxemia: } \\
\text { methadone: } 13 \% \\
\text { fentanyl: } 8 \% \\
\text { Sedation: } \\
\text { methadone: } 83 \% \\
\text { fentanyl: } 90 \%\end{array}$ \\
\hline d & Matot, 2004 & $\begin{array}{l}\text { methadone: } \\
2.47-4.37 \\
\text { clonidine: } \\
1.53-4.63 \\
\text { bupivacain } \\
\text { e: } \\
2.0-4.6\end{array}$ & NR & NR & $\begin{array}{l}\text { Per NRS, } \\
\text { pain score } \\
\text { was not } \\
\text { statistically } \\
\text { significant } \\
\text { between the } \\
\text { three } \\
\text { groups } \\
\text { throughout } \\
\text { the study } \\
\text { period } \\
\text { By POD 3, } \\
\text { bupivacaine } \\
\text { group } \\
\text { required } \\
\text { more }\end{array}$ & NR & $\begin{array}{l}\text { diclofenac } \\
\text { doses } \\
\text { required } \\
(\mathrm{mg}) \text { : } \\
\text { methadone } \\
: 300 \pm 120 \\
\text { clonidine: } \\
325 \pm 90 \\
\text { bupivacain } \\
\text { e: } 575 \pm \\
115\end{array}$ & $\begin{array}{l}\text { Sedation: } \\
\text { methadone: } 14 \% \\
\text { clonidine: } 18 \% \\
\text { bupivacaine: } 0 \% \\
\text { Hypotension: } \\
\text { methadone: } 0 \% \\
\text { clonidine: } 24 \% \\
\text { bupivacaine: } 24 \% \\
\text { Vomiting: } \\
\text { methadone: } 28 \% \\
\text { clonidine: } 6 \% \\
\text { bupivacaine: } 12 \% \\
\text { Pruritis: } \\
\text { methadone: } 21 \% \\
\text { clonidine: } 0 \%\end{array}$ \\
\hline
\end{tabular}




\begin{tabular}{|c|c|c|c|c|c|c|c|}
\hline $\begin{array}{l}\text { Author, } \\
\text { Year }\end{array}$ & $\begin{array}{l}\text { Surgery } \\
\text { Time } \\
\text { (hours) }\end{array}$ & $\begin{array}{l}\text { Time to } \\
\text { Extubation } \\
\text { (hours) }\end{array}$ & $\begin{array}{l}\text { Time to } 1^{\text {st }} \\
\text { rescue } \\
\text { analgesic } \\
\text { (hours) }\end{array}$ & $\begin{array}{l}\text { NRS in first } \\
24 \text { hours }\end{array}$ & $\begin{array}{l}\text { NRS } \\
\text { Extended } \\
\text { period }\end{array}$ & $\begin{array}{l}\text { Reported } \\
\text { rescue } \\
\text { drug use }\end{array}$ & Adverse Events \\
\hline & & & & $\begin{array}{l}\text { diclofenac } \\
\text { to achieve } \\
\text { NRS scores } \\
<3 \text { at rest } \\
\text { and }<4 \\
\text { while } \\
\text { coughing }\end{array}$ & & & $\begin{array}{l}\text { bupivacaine: 0\% } \\
\text { Bradycardia: } \\
\text { methadone: 0\% } \\
\text { clonidine: 12\% } \\
\text { bupivacaine: 0\% } \\
\text { Urinary } \\
\text { retention: } \\
\text { methadone: 28\% } \\
\text { clonidine: 12\% } \\
\text { bupivacaine: } 30 \% \\
\text { Limb Weakness: } \\
\text { methadone: 0\% } \\
\text { clonidine: } 0 \% \\
\text { bupivacaine: } 12 \%\end{array}$ \\
\hline
\end{tabular}




\begin{tabular}{|c|c|c|c|c|c|c|c|c|}
\hline & $\begin{array}{l}\text { Author, } \\
\text { Year }\end{array}$ & $\begin{array}{l}\text { Surgery } \\
\text { Time } \\
\text { (hours) }\end{array}$ & $\begin{array}{l}\text { Time to } \\
\text { Extubation } \\
\text { (hours) }\end{array}$ & $\begin{array}{l}\text { Time to } 1^{\text {st }} \\
\text { rescue } \\
\text { analgesic } \\
\text { (hours) }\end{array}$ & $\begin{array}{l}\text { NRS in first } \\
24 \text { hours }\end{array}$ & $\begin{array}{l}\text { NRS } \\
\text { Extended } \\
\text { period }\end{array}$ & $\begin{array}{l}\text { Reported } \\
\text { rescue } \\
\text { drug use }\end{array}$ & Adverse Events \\
\hline e & Perez, 2007 & $\begin{array}{l}\text { methadone: } \\
2.3-3.5 \\
\text { ropivacaine } \\
\text { with } \\
\text { fentanyl } \\
\text { (PCEA): } \\
2.48-3.32\end{array}$ & $\begin{array}{l}\text { Extubated at } \\
\text { conclusion of } \\
\text { surgery prior } \\
\text { to arrival to } \\
\text { PACU/ICU }\end{array}$ & NR & 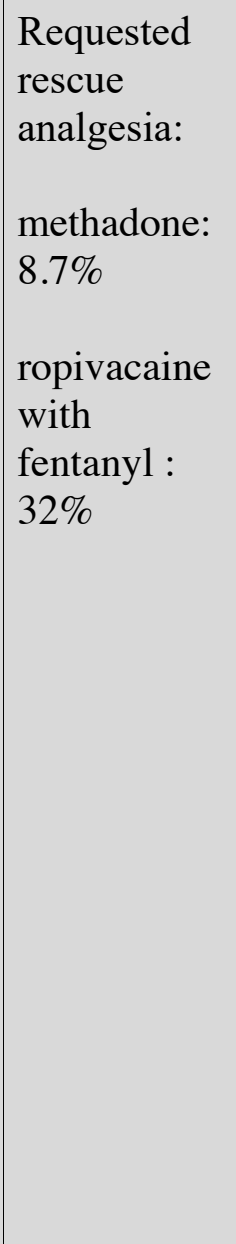 & $\begin{array}{l}\text { At } 48 \\
\text { hours: } \\
\text { Requested } \\
\text { rescue } \\
\text { analgesia: } \\
\text { methadone: } \\
0 \% \\
\text { ropivacaine } \\
\text { with } \\
\text { fentanyl : } \\
28 \%\end{array}$ & & $\begin{array}{l}\text { Sedation: } \\
\text { methadone: } \\
\text { 1 h: } 39.1 \% \\
24 \text { h: } 13 \% \\
24 \text { h: } 13 \% \\
\\
\text { PCEA } \\
1 \text { h: } 28 \%, \\
24 \text { h: } 0 \% \\
24 \text { h: } 4 \% \\
\text { Hypotension } \\
\text { methadone: } \\
1 \text { h: } 0 \\
24 \text { h: } 8.7 \% \\
24 \text { h: } 4.3 \% \\
\text { PCEA: } \\
1 \text { h: } 28 \%, \\
24 \text { h: } 12 \% \\
24 \text { h: } 0 \\
\text { Vomiting } \\
\text { methadone: } \\
1 \text { h: } 13 \% \\
24 \text { h: } 13 \% \\
24 \text { h: } 13 \% \\
\text { PCEA: }\end{array}$ \\
\hline
\end{tabular}




\begin{tabular}{|c|c|c|c|c|c|c|c|}
\hline $\begin{array}{l}\text { Author, } \\
\text { Year }\end{array}$ & $\begin{array}{l}\text { Surgery } \\
\text { Time } \\
\text { (hours) }\end{array}$ & $\begin{array}{l}\text { Time to } \\
\text { Extubation } \\
\text { (hours) }\end{array}$ & $\begin{array}{l}\text { Time to } 1^{\text {st }} \\
\text { rescue } \\
\text { analgesic } \\
\text { (hours) }\end{array}$ & $\begin{array}{l}\text { NRS in first } \\
24 \text { hours }\end{array}$ & $\begin{array}{l}\text { NRS } \\
\text { Extended } \\
\text { period }\end{array}$ & $\begin{array}{l}\text { Reported } \\
\text { rescue } \\
\text { drug use }\end{array}$ & Adverse Events \\
\hline & & & & & & & $\begin{array}{l}1 \text { h: } 12 \% \\
24 \text { h: } 0 \% \\
24 \text { h: } 4 \% \\
\text { Pruritis } \\
\text { methadone: } \\
1 \text { h } 0 \% \\
24 \text { h: } 4.3 \% \\
24 \text { h: } 0 \% \\
\text { PCEA: } \\
1 \text { h: } 0 \% \\
24 \text { h: } 4 \% \\
24 \text { h: } 4 \%\end{array}$ \\
\hline
\end{tabular}

PONV $=$ Postoperative Nausea/Vomiting

$\mathrm{NR}=$ Not Reported 